WSRC-TR-2002-00435

Rev. 0

Keywords: Wastewater Treatment, F-Area Seepage Basins, I-129, Tc-99, Mercury, Silver Impregnated Activated Carbon, Ion Exchange

Retention: Permanent

\title{
Laboratory Evaluation of I-129 and Tc-99 Removal at the F-Area Water Treatment Units
}

November 11, 2002

\section{S. M. Serkiz}

Waste Processing Technology,

SRTC, Building 773A

J. P. Kanzleiter

ER Engineering

Environmental Restoration Division, 704-22G
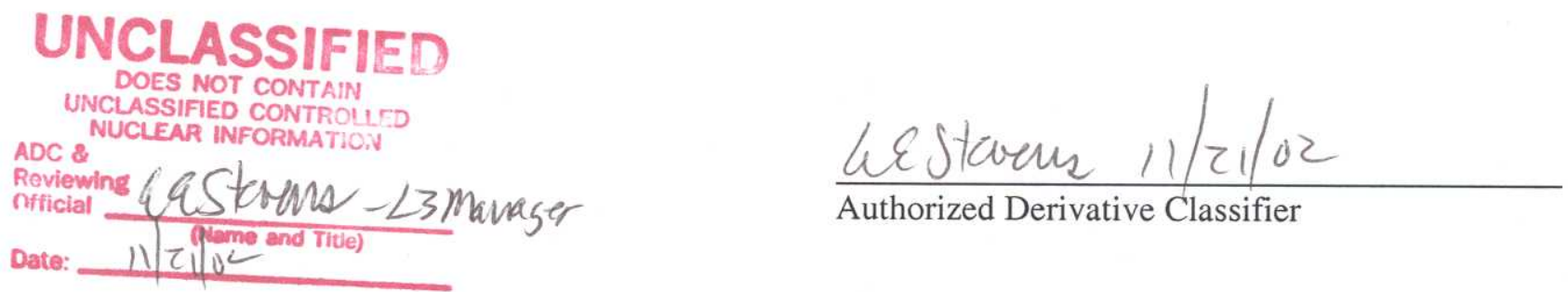

Westinghouse Savannah River Company

Savannah River Site

Aiken, SC 29808

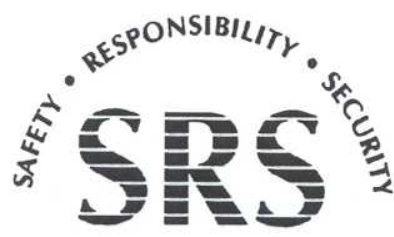

SAVANNAH RIVER SITE

Prepared for the U.S. Department of Energy Under

Contract Number DE-AC09-96SR18500 
This document was prepared in conjunction with work accomplished under Contract No. DE-AC09-96SR18500 with the U. S. Department of Energy.

\section{DISCLAIMER}

This report was prepared as an account of work sponsored by an agency of the United States Government. Neither the United States Government nor any agency thereof, nor any of their employees, makes any warranty, express or implied, or assumes any legal liability or responsibility for the accuracy, completeness, or usefulness of any information, apparatus, product or process disclosed, or represents that its use would not infringe privately owned rights. Reference herein to any specific commercial product, process or service by trade name, trademark, manufacturer, or otherwise does not necessarily constitute or imply its endorsement, recommendation, or favoring by the United States Government or any agency thereof. The views and opinions of authors expressed herein do not necessarily state or reflect those of the United States Government or any agency thereof.

This report has been reproduced directly from the best available copy.

Available for sale to the public, in paper, from: U.S. Department of Commerce, National Technical Information Service, 5285 Port Royal Road, Springfield, VA 22161, phone: (800) 553-6847, fax: (703) 605-6900

email: orders@ntis.fedworld.gov

online ordering: http://www.ntis.gov/help/index.asp

Available electronically at http://www.osti.gov/bridge

Available for a processing fee to U.S. Department of Energy and its contractors, in paper, from: U.S. Department of Energy, Office of Scientific and Technical Information, P.O. Box 62, Oak Ridge, TN 37831-0062,

phone: (865)576-8401,

fax: (865)576-5728

email: $\underline{\text { reports@ adonis.osti.gov }}$ 


\title{
KEY WORDS:
}

Wastewater Treatment,

F-Area Seepage Basins, I-129, Tc-99,

Mercury, Silver Impregnated

Activated Carbon, Ion Exchange

Retention: Permanent

\section{Laboratory Evaluation of I-129 and Tc-99 Removal at the F-Area Water Treatment Units (U)}

\author{
Authors \\ S. M. Serkiz \\ Westinghouse Savannah River Company \\ J. P. Kanzleiter \\ ER Engineering \\ Environmental Restoration Division \\ Laura McDowell-Boyer \\ Alara Environmental Analysis, Inc.
}

November 11, 2002

Westinghouse Savannah River Company Savannah River Site

Aiken, SC 29808

Prepared for the U.S. Department of Energy

under Contract No. DE-AC09-96SR18500 


\section{Authors}

$\frac{\text { Strum an. Se tky }}{\text { S. M. Serkiz, Waste Disposal \& Environtmental Development }} \frac{11 / 14 / 02}{\text { Date }}$

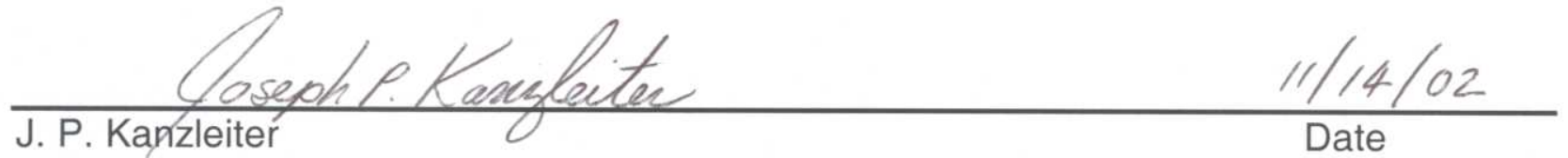

ER Engineering - Environmental Restoration Division

\section{Design Check}

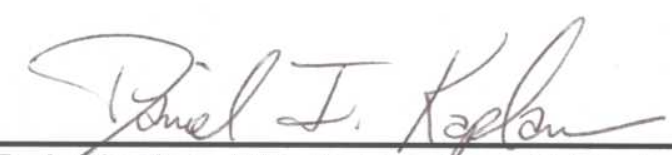

D. I. Kaplan, Waste Dispbsal \& Environmental Development (per Manual E7, Procedure 2.40)

\section{Approvals}

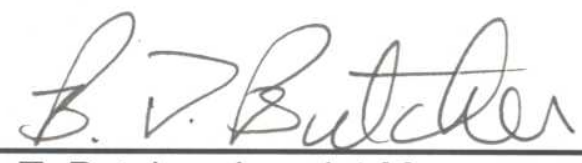

B. T. Butcher, Level 4 Manager

Waste Disposal \& Environmental Development - SRTC

\section{$4 / 19 / 02$}

Date
John Adams

ER Engineering - Environmental Restoration Division

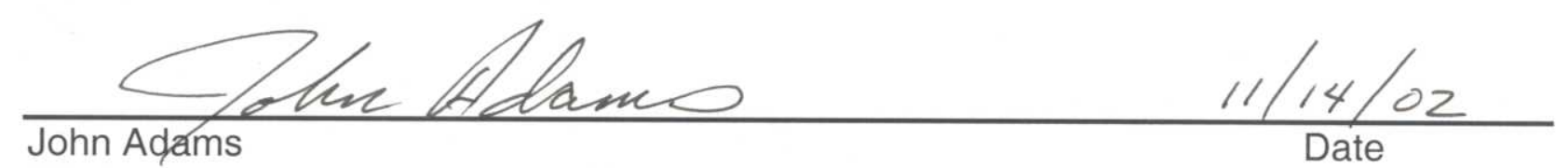

$11 / 14 / 02$

Date 


\section{Table of Contents}

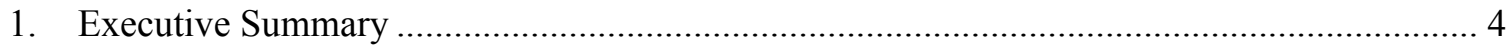

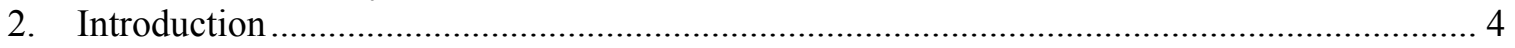

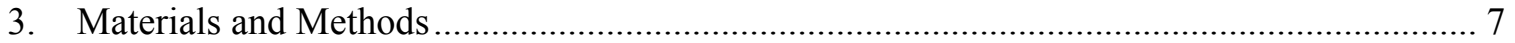

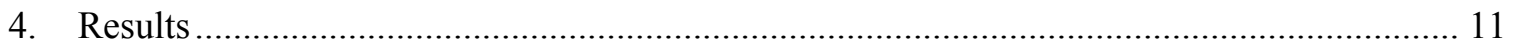

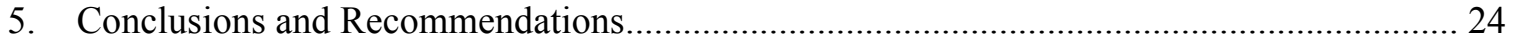

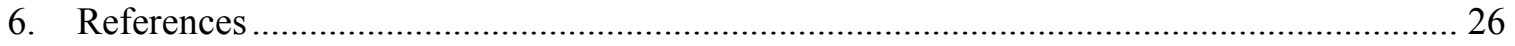

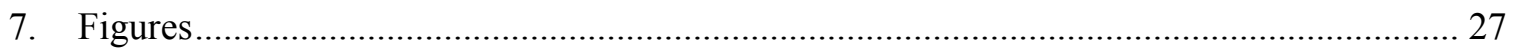

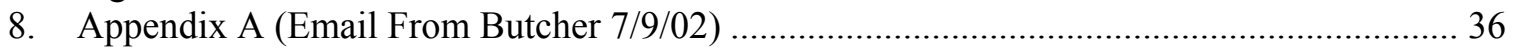

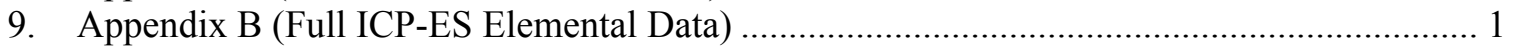

\section{List of Tables}

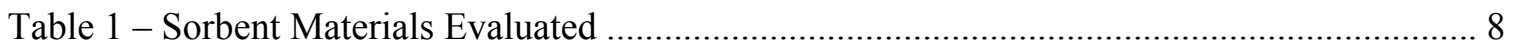

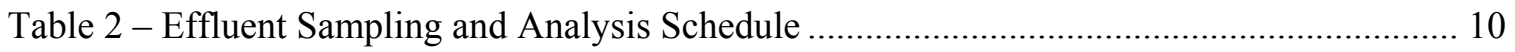

Table 3 - Radiochemical Data for F WTU Feedwater (pCi/L) ................................................. 12

Table 4 - Elemental Composition Data for F WTU Feedwater $(\mathrm{mg} / \mathrm{L})$...................................... 12

Table 5 - Radiochemical Data Concept 1 (Silver Modified Carbons) .......................................... 15

Table 6 - ICP-ES Silver and Uranium Data Concept 1 (Silver-Modified Carbons) ....................... 16

Table 7 - TCLP Silver Data for Silver Modified Carbons ........................................................... 17

Table 8 - Ag and U Post Column Test Data for Silver Modified Carbons ................................... 18

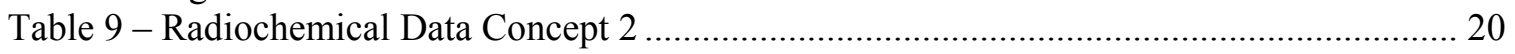

Table 10 - Radiochemical Data Concept 3 (Commercial Anion Resin) .................................... 22

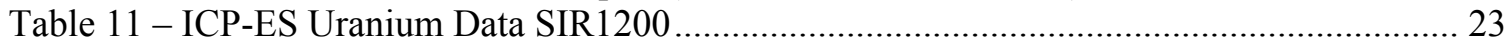

Table 12 -U Post Column Test Data for Commercially Available Resins .................................. 24

\section{List of Figures}

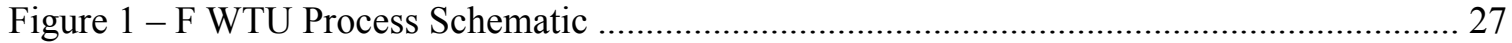

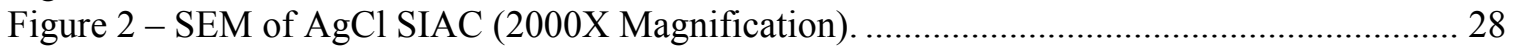

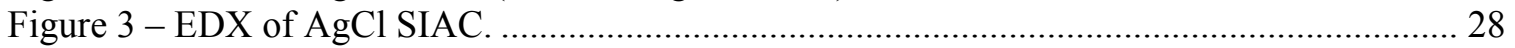

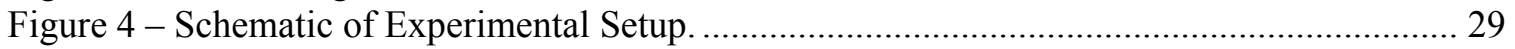

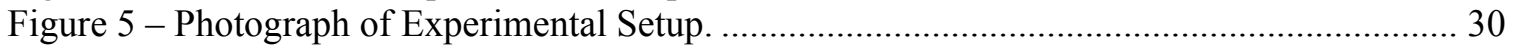

Figure 6 - I-129 Effluent Activity for Concept 1 (Silver Modified Carbons)................................ 31

Figure 7 - Tc-99 Effluent Activity for Concept 1 (Silver Modified Carbons)............................... 32

Figure 8 - I-129 Effluent Activity for Concept 3 (Anion Resin)................................................ 33

Figure 9 - Tc-99 Effluent Activity for Concept 3 (Anion Resin). ............................................. 34 


\section{Executive Summary}

The current process configuration of the F-Groundwater Treatment Unit (F-WTU) is limited in its ability to remove I-129 from the feed water. Furthermore, because the disposal limits at SRS for I-129 bearing waste are low, disposal of both the spent ion exchange (IX) resin and filtercake from the clarification process has been a complex problem. The focus of this study was to investigate the effectiveness of a variety of sorption materials to remove problematic anions (e.g., I-129) present in feed water at the F-WTU. The results from this study suggest that the silvermodified carbons and the commercially available anion exchange resin, SIR-1200, were effective in removing I-129 from the feed water to low levels. Pilot or field testing at the F-WTU on a subset of these materials is recommended to confirm these findings and to evaluate the potential benefits for full-scale implementation.

\section{Introduction}

Removal of anions at the F- and H- Seepage Basins Groundwater Treatment Units (WTUs) has been problematic in terms of low decontamination factors (DFs) and rapid resin exhaustion. It is believed that these problems stem from the lack of target contaminant sorption specificity and, to a lesser extent, lack of resin exchange capacity. Currently anion exchange is performed as a polishing step after clarification (see Figure 1 for process schematic).

Additionally, because the SRS disposal limits for I-129 bearing waste are low, disposal of both the spent ion exchange (IX) resin and filtercake from the clarification process has also been problematic. Estimates based on disposal costs and waste production estimates from Butcher (2002) indicate that cost savings would be on the order of \$7-8 M if filtercake and spent cation resins could be disposed of in slit trenches at SRS rather than at the Nevada Test Site. This, it is believed, could be accomplished if I-129 can be kept out of these wastes and/or if the I-129 is a sufficiently stable secondary waste to prevent I-129 leaching.

In the summer of 2001, work was initiated to evaluate alternative separation processes (moving anion exchange to the front end of the process) and materials (i.e., ion exchange resins and sorbents) for the removal of I-129 and Tc-99 in groundwater being treated at the F-Area Seepage Basins WTU. The general approach of this work was to evaluate a number of anion removal materials for their ability to remove and sequester I-129 and Tc-99 from actual F-Area WTU feedwater in a series of laboratory column experiments. The performance criteria for these materials are (1) selectivity of the sorbent for I-129 and Tc-99 (i.e., target contaminant DF); (2) capacity of the sorbent for the target contaminant(s) (i.e., contaminant breakthrough profile); (3) the ability of the sorbent to produce a stable secondary waste material; and (4) cost. These criteria were evaluated in three separate concepts:

- Silver-modified activated carbons,

- concurrent I-129/mercury removal, and

- screening of commercially available organic anion exchange resins.

These approaches are described in more detail below. 


\subsection{Concept 1 - Silver-Modified Activated Carbons}

Recent work has been completed as a joint project between SRTC and Clemson University on the use of silver impregnated activated carbon (SIAC) sorption media for the removal of iodide from aqueous waste streams (Hoskins et al. 2002 and Cumbie, 2002). SIACs are granular activated carbons that have been impregnated with silver to form a composite reactive surface of silver and activated carbon. Silver can be impregnated in a variety of chemical forms with the most common being metallic silver $[\mathrm{Ag}(0)]$. As described below, in addition to SIAC- $\operatorname{Ag}(0)$, advantageous solubility controls associated with silver chloride $(\mathrm{AgCl})$ lead us to investigate this chemical form of silver impregnation in SIAC as the SIAC-AgCl composite material.

Note that the SIAC media is different than the activated carbon used at the WTUs by Adtechs during startup. The Adtechs' unmodified activated carbon material did not effectively remove the iodine, was prone to clogging due to inefficient operating conditions at that time, and was a source for biological growth. In order to elucidate the role of the activated carbon backbone on anion removal, we chose to include in the study the unmodified activated carbon material that was the precursor for two of the SIACs.

Costs for these SIAC materials (\$3-\$8/lb) are competitive with the Dowex-21K and SIR 1200 anion exchange resins used at the F WTU (approximately $\$ 4.6 / \mathrm{lb}$ and $\$ 3.7 / \mathrm{Ib}$, respectively) and have the potential for a substantially increased operational life.

The work by Hoskins et al (2002) showed that SIAC impregnated with silver metal [SIAC-Ag(0)] exhibited high DFs for iodide removal over a wide range of chemical conditions. Furthermore, once this material was contacted with iodide, leaching of iodide from the secondary waste was not measurable (high $\mathrm{K}_{d}$ values). The SIAC-Ag(0) material, however, leached silver when iodide was absent from the aqueous waste stream and the $\mathrm{pH}$ was low. The low-pH conditions of feedwater at the F-Area WTU makes silver leaching from the SIAC-Ag(0) material a concern. While another approach for this material could be as a post-clarifier anion exchange step where the $\mathrm{pH}$ of the system is alkaline, this approach and the current WTU configuration would not keep I-129 out of the filtercake clarifier waste.

Work by Cumbie (2002) has shown that activated carbon can be impregnated with silver chloride $(\mathrm{AgCl})$ rather than silver metal $[\mathrm{Ag}(0)]$ and that the $\mathrm{SIAC}-\mathrm{AgCl}$ has the potential to overcome the problems of silver leaching observed for SIAC-Ag(0). These silver leaching observations are consistent with the solubility limit for the $\mathrm{AgCl}$ solid reported in the MINTEQA2 thermodynamic database (Allison, 1991) of $\mathrm{K}_{\mathrm{sp}}=1.8 \mathrm{E}-10$ which corresponds to solubility of $1.44 \mathrm{ppm} \mathrm{Ag}$ in deionized water. The presence of naturally occurring chloride, however, will reduce the soluble silver level significantly. For example, at the average river water concentration for chloride of $5.6 \mathrm{mg} / \mathrm{L}$ (Stumm and Morgan, 1995) the solubility of Ag drops to $0.12 \mathrm{ppm}$. Additionally, if silver becomes soluble, the activated carbon has the potential of removing soluble silver through nonspecific sorption to the surface which will further reduce soluble silver concentrations. 
The basic approach to testing silver modified carbons for I-129 removal was to develop, produce, and characterize SIAC based on a sparingly soluble $\mathrm{AgCl}$ chemistry and then evaluate these materials in the laboratory using actual F-Area WTU influent water in column tests. To assess the performance changes associated with the SIAC- $\mathrm{AgCl}$ approach, the base activated carbon (no silver) and SIAC- $\operatorname{Ag}(0)$ materials were also evaluated side-by-side using actual F-Area WTU influent water in column tests. In these tests, I-129 DF, sorption kinetics, and SIAC sorption capacity will all be measured. In order to evaluate secondary waste stability, both the starting SIACs and the SIACs after reaction with the F-Area feedwater were subjected to TCLP extractions and these extracts analyzed for silver content.

\subsection{Concept 2 - Concurrent I-129/Mercury Removal}

As in Concept 1, the second concept investigated in this study also takes advantage of the low solubility of transition metal-halide solids [in this case mercuric $\left(\mathrm{Hg}^{2+}\right)$ iodide]. Because $\mathrm{Hg}$ is a toxic metal and has a very low regulatory limit ( $2 \mathrm{ppb}$ in groundwater), the addition of an engineered mercury containing sorbent was thought to be potentially unacceptable from a regulatory standpoint. Rather, because low levels of $\mathrm{Hg}$ are present in groundwater treated in the WTU, this concept involves the creation of a $\mathrm{Hg}$ containing resin in the WTU by sorption of $\mathrm{Hg}$ from contaminated groundwater onto a commercially available $\mathrm{Hg}$ specific resin during normal WTU operations. The hypothesis was that this in situ $\mathrm{Hg}$-loaded resin would then act as sorbent capable of highly selective removal of I-129 as a mercuric iodide solid.

This hypothesis was developed based on recent data on the leaching of I-129 from spent Effluent Treatment Facility mercury-specific resin (GT-73) that showed concurrent loading of I-129 and mercury (Hg) (Kaplan et al, 1999). Furthermore, the leach rate of both I-129 and Hg from these resins was found to be exceedingly small. It was thought that iodine and mercury were removed from solution by the following mechanism: (1) $\mathrm{Hg}$ sorption to the $\mathrm{Hg}$-specific resin and (2) reaction of the sorbed $\mathrm{Hg}$ with I-129 to form a sparingly soluble mercury iodine solid. For example, mercuric iodide $\left[\mathrm{Hg}(\mathrm{II}) \mathrm{I}_{2}\right.$ (s)] has a solubility product of 10E-28.62 (Lindsay, 1979). This solubility product corresponds to an equilibrium aqueous iodide concentration of 7.2E-5 ppm. If the conservative assumption were made that all iodide is in the isotope I-129, then this would correspond to an activity in solution of about $30 \mathrm{pC}_{\mathrm{i}} / \mathrm{L}$. Therefore, if solubility control of I-129 can be achieved by the mechanism described above, then this would ensure I-129 leachate concentrations from the resulting secondary waste below the South Carolina Department of Health and Environmental Control Underground Injection Control (UIC) Permit limit of 50 $\mathrm{pC}_{\mathrm{i}} / \mathrm{L}$.

In a previous bench-scale study (Monson et al., 2000), GT-73, SR-4, and SIR-200 resins were the mercury specific ion exchange materials shown to be the most effective for removal of mercury from process water from the H-Area WTU. Based on this study and data collected from the ETF study, GT-73 was thought to be a good candidate for $\mathrm{Hg}$ removal and the production of a mercury containing sorbent. This concept was evaluated with GT-73 resin that was loaded with $\mathrm{Hg}$ as a mercuric nitrate prior to contacting with WTU feedwater and a second column of GT-73 resin that had not been exposed to mercury prior to contacting with WTU feedwater. These materials (GT-73 resin and GT-73 resin loaded with Hg) were tested in the laboratory using actual F-Area WTU influent water in column studies. These column studies were designed to provide data to estimate sorption capacity, competitive ion sorption, and operational life for these materials. 


\subsection{Concept 3 - Screening of Commercially Available Organic Anion Resins}

The anion exchange resin previously employed at the F-WTU, Dowex-21K, is an expensive specialty anion exchange resin designed to remove uranium in the anionic form (carbonate complexes) in the uranium mining industry. Recently, a study conducted at the F-WTU (Kanzleiter, 2001) indicated that the SIR-1200 exhibited better performance when compared to the DOWEX-21K. The SIR-1200 has since replaced the DOWEX $21 \mathrm{~K}$ at the F- and H-WTUs based on improved performance (i.e., higher DF and longer runtime) at a lower cost.

The current location for anion removal (i.e., I-129 and Tc-99) is after the clarifier where the $\mathrm{pH}$ has been raised to a value between 7 and 9. At these higher $\mathrm{pH}$ values, anion removal is less effective due to hydroxide anion competition for sorption onto the resin. This study examined the removal of anions from the WTU feedwater, at lower $\mathrm{pH}$ values (prior to $\mathrm{pH}$ adjustment), where anion removal should be more effective.

To evaluate Concept 3, SIR-1200 and ResinTech's WBG-30, a high capacity, weak base granular anion exchange resin were tested in the laboratory using actual F-Area WTU influent water in column studies. These column studies were designed to provide data to estimate sorption capacity, competitive ion sorption, and operational life for these materials.

\section{Materials and Methods}

The materials and methods section describes the (1) development, pretreatment, and characterization of sorbent materials used in this study, (2) experimental protocols used in the column testing of sorbent materials with actual F Area WTU feedwater, and (3) analytical methods used in this testing.

\subsection{Materials}

Eight different sorbents were evaluated in this study and are listed in Table 1. For the silvermodified carbon studies, two commercially prepared bituminous coal based SIAC-Ag(0)s with different silver contents by weight [1.05\% (TOG-NDS-20x50, Calgon Corporation) and $0.05 \%$ (Nusorb A 20x40, Nucon International, Inc.)] were used as starting materials for this study. These commercially available SIACs were reacted with hydrochloric acid to form SIAC-AgCl materials for further evaluation. The reaction conditions, time and acid concentration, were optimized using material characterization of the reacted material. Scanning electron microscopy (SEM) and energy dispersive x-ray analysis (EDX) were used to evaluate the solid phase. After reaction, the spent hydrochloric acid solution was analyzed for silver content. The details of these analyses and the development of reaction conditions are contained in Cumbie, 2002. The SEM and EDX show that this treatment process is capable of converting silver metal in the SIAC to silver chloride. Once the reaction conditions were optimized, larger batches of SIAC-AgCl materials were produced for this study. Representative SEM and EDX data of this material $(1.05 \% \mathrm{Ag})$ are included as Figures 2 and 3 respectively. 
For comparison purposes, the base activated carbon (containing no silver) used to produce the $1.05 \%$ SIAC- $\operatorname{Ag}(0)$, and the $1.05 \%$ SIAC- $\operatorname{Ag}(0)$ used to produce the SIAC-AgCl were evaluated against the SIAC- $\mathrm{AgCl}$ with 0.05 and 1.05 weight percent silver. For testing the concurrent removal of mercury and I-129, the mercury specific ion exchange resin, GT-73 was evaluated. This ion exchange resin was tested "as received" and after being loaded with mercury. For the mercury-loaded resin, the resin was pretreated with 100 pore volumes of $2 \mathrm{ppb}$ mercuric nitrate $\left(\mathrm{Hg}\left(\mathrm{NO}_{3}\right)_{2}\right)$ via a peristaltic pump at a flow rate of $2 \mathrm{ml}$ per minute. The commercially available anion exchange resins, SIR-1200 and WBG-30, were tested as received.

\begin{tabular}{|c|c|c|c|}
\hline Material & Source & Pretreatment & $\begin{array}{l}\text { Sorbent Added } \\
\text { to Column }(\mathrm{g})\end{array}$ \\
\hline $\begin{array}{l}\text { Base Activated Carbon }(1.05 \% \\
\text { SIAC-Ag(0) precursor) }\end{array}$ & $\begin{array}{l}\text { Calgon } \\
\text { Corporation }\end{array}$ & None & 11.12 \\
\hline $\begin{array}{l}\text { SIAC-Ag(0) }(1.05 \% \mathrm{Ag}) \text { (Sample } \\
\text { TOG-NDS-20x50) }\end{array}$ & $\begin{array}{l}\text { Calgon } \\
\text { Corporation }\end{array}$ & None & 12.42 \\
\hline SIAC-AgCl $(0.05 \% \mathrm{Ag})$ & Treated in House & $\begin{array}{l}\mathrm{HCl} \text { Treatment of Nusorb A } \\
20 \times 40\end{array}$ & 12.25 \\
\hline SIAC-AgCl $(1.05 \% \mathrm{Ag})$ & Treated in House & $\begin{array}{l}\text { HCl Treatment of Calgon } \\
\text { TOG-NDS-20x50 }\end{array}$ & 14.11 \\
\hline GT-73 Resin & Rohm \& Haas & None & 24.86 \\
\hline GT-73 Resin Hg Loaded & Treated in House & $\begin{array}{l}2 \mathrm{ppb} \mathrm{HgNO}_{3} \text { Treatment of } \\
\text { Rohm \& Haas GT-73 Resin }\end{array}$ & 25.30 \\
\hline SIR-1200 Anion Resin & ResinTech & None & 17.02 \\
\hline WBG-30 Anion Resin & ResinTech & None & 14.02 \\
\hline
\end{tabular}

\subsection{Column Studies}

All column testing was conducted using established test methods and the general approach contained in the following procedures.

- ASTM D 1782-91, "Test Methods for Operating Performance of Particulate CationExchange Materials"

- ASTM D 2187-94, "Standard Test Methods for Physical and Chemical Properties of Particulate Ion Exchange Resins"

Because this study was designed for the rapid screening of the performance of a large number of resin materials rather than a detailed characterization of the materials, minor modifications to the ASTM procedures (column dimensions, mass of resin, and flow rate) were necessary. 
A schematic of the experimental setup is presented in Figure 4 with photographs of the setup in Figure 5. The columns used in this study were constructed of glass and were $1.5 \mathrm{~cm}$ in diameter and $15 \mathrm{~cm}$ in height (i.e., a total column volume of $26.5 \mathrm{~mL}$ ) and were obtained from the Kontes Glass Co. Eight glass columns were each filled to approximately three-quarters height and the weight recorded (see Table 1). The bedvolume of material is approximately $20 \mathrm{ml}$, and at an assumed porosity of 40 percent, one porevolume is about $8 \mathrm{~mL}$. After the solid material was packed into each column, a plug of glass wool was inserted to fill the remaining space at the top of the column. Each column was then capped. A straight line from the feed water was used to evaluate the influent concentration (i.e., column blank).

Feed water from the F-Area WTU was used as influent solution for the column study. Personnel from the Environmental Restoration Department delivered two hundred liters of F-WTU feedwater, contained in eight 25-liter carboys, to SRTC for use in this study. Each of the columns were "pretreated" with one liter of feed water at a flow rate of $5.0 \mathrm{ml} / \mathrm{min}$ (approximately 50 bedvolumes) prior to chemical analyses. This "pretreatment" was completed in order to allow the columns to achieve steady state conditions prior to sampling. After preconditioning, the experiment was run continuously (24-hour a day basis) at an influent pumping rate of $5.0 \mathrm{ml} / \mathrm{min}$. The column testing lasted about 2.8 days or a total effluent volume of about 20-L. At predetermined cumulative effluent volumes, samples were collected for analysis as outlined in Table 2.

The lab column study was conducted at a flow rate that results in approximately 15 bedvolumes per hour and 37.5 porevolumes per hour. This flow rate per bedvolume results in a contact time of 4 minute per bedvolume. In comparison, an anion exchange vessel at the F-WTU is normally filled with about 56 cubic feet (or 419 gallons) of resin. At a porosity of 40 percent, one porevolume is about 22.4 cubic feet or 168 gallons. The average flow rate through the vessel is approximately $40 \mathrm{GPM}$ (or $2400 \mathrm{GPH}$ ) that results in approximately 5.7 bedvolumes per hour and 14.3 porevolumes per hour. The plant flow rate per bedvolume results in a contact time of about 10.5 minutes. The column study flow rate was about 2.6 times faster than those normally experienced for anion removal at the F WTU. I-129 breakthrough at the F-WTU has been estimated at approximately 600 bedvolumes (approximately 4.3 days of continuous operation under full-flow condition). The column study at 1050 bedvolumes equates to approximately 8 days of plant operations.

At the conclusion of the column study, solids from each sorbent were extracted and selected solids digested. Digestion was accomplished using an acid microwave process and was completed by the Analytical Development of SRTC. The liquid from the digestion process was analyzed by ion coupled emission spectrophotometry (ICP-ES) for RCRA Metals and uranium. Extraction was conducted using the USEPA's toxicity characteristic leaching procedure (TCLP) and the extract analyzed by cold vapor atomic absorption spectrophotometry for mercury and ICP-ES for RCRA metals and uranium. 


\begin{tabular}{|c|c|l|}
\hline \multicolumn{2}{|c|}{ Table $2-$ Effluent Sampling and Analysis Schedule } \\
\hline $\begin{array}{c}\text { Effluent } \\
\text { Volume (L) }\end{array}$ & $\begin{array}{c}\text { Average } \\
\text { Porevolume }\end{array}$ & Analysis \\
\hline 1 to 2 & 75 & Iodine-129, ICP-ES Metals \\
\hline 2 to 3 & 125 & Iodine-129, ICP-ES Metals \\
\hline 3 to 4 & 175 & Iodine-129, ICP-ES Metals \\
\hline 4 to 6 & 250 & Tc-99, Gross Alpha/Non-Volatile Beta, ICP-ES Metals \\
\hline 6 to 7 & 325 & Iodine-129, ICP-ES Metals \\
\hline 7 to 8 & 375 & Iodine-129, ICP-ES Metals \\
\hline 8 to 9 & 425 & Iodine-129, ICP-ES Metals \\
\hline 9 to 11 & 500 & Tc-99, Gross Alpha/Non-Volatile Beta, ICP-ES Metals \\
\hline 11 to 12 & 575 & Iodine-129, ICP-ES Metals \\
\hline 12 to 14 & 650 & Tc-99, Gross Alpha/Non-Volatile Beta, ICP-ES Metals \\
\hline 14 to 15 & 725 & Iodine-129, ICP-ES Metals \\
\hline 15 to 17 & 800 & Tc-99, Gross Alpha/Non-Volatile Beta, ICP-ES Metals \\
\hline 17 to 18 & 875 & Iodine-129, ICP-ES Metals \\
\hline 18 to 20 & 950 & Tc-99, Gross Alpha/Non-Volatile Beta, ICP-ES Metals \\
\hline 20 to 21 & 1025 & Iodine-129, ICP-ES Metals \\
\hline
\end{tabular}

Note: All effluent samples from silver containing carbon columns were also analyzed for Ag and uranium by ICP-ES at the ADS of SRTC.

\subsection{Analysis and QA/QC}

GEL Laboratories of Charleston, SC analyzed effluent samples under contract AB80091N with WSRC. Details of analytical procedures and QA requirements for these analyses are contained in this contract. Standard QA practices were utilized to maximize usefulness of the experimental data. This included: a) use of an accredited analytical laboratory; b) routine submittal of experimental blanks; and c) submittal of experimental replicates. The SRTC Conduct of R\&D Manual was employed for this work and a Hazard Screening Checklist was completed.

\subsubsection{Radiochemical Analyses}

GEL Laboratories conducted all radiochemical analyses (Tc-99, I-129, gross alpha and nonvolatile beta). Serkiz and Reboul (1999 Clearwell IX Study) reported that alpha emitters included U-238, U-234, Cm-244, Am-241, Th-230, and Ra-226 and the beta emitters included Sr90, Y-90 (Y-90 is in secular equilibrium with Sr-90), and Ra-228, as well as potentially volatile C-14, Tc-99, and I-129.

\subsubsection{Elemental Composition}

At selected effluent volumes $30-\mathrm{mL}$ aliquots were collected for elemental composition analysis by ICP-ES and mercury using cold vapor atomic absorption (AA) spectrophotometry by the ADS of SRTC. Samples were analyzed by ICP-ES without filtration and were acidified to a $\mathrm{pH}$ of approximately 1 with ultra-pure nitric acid prior to analysis. ICP-ES was used to analyze for major ion chemistry (e.g., Al, Si, Fe), RCRA metals, and uranium. Mercury was analyzed on unpreserved samples using cold vapor atomic absorption (AA) spectrophotometry. 
Liquids from microwave dissolutions and TCLP extractions were analyzed by ICP-ES without preservation.

\section{Results}

This section describes the results of ion exchange optimization testing and is organized in four sections: feedwater characterization; Concept 1 - Silver Modified Activated Carbons; Concept 2 Concurrent I-129/Mercury Removal; Concept 3 - Screening of Commercially Available Organic Anion Resins, and Solids Characterization.

\subsection{F-WTU Feedwater Characterization}

Samples of column influent were collected at predetermined volumes during column testing of sorbent materials and subsequently analyzed for I-129, Tc-99, gross alpha, and nonvolatile beta. For these samples, the average activities were determined to be $56 \mathrm{pCi} / \mathrm{L}$ for $\mathrm{I}-129,64 \mathrm{pCi} / \mathrm{L}$ for Tc-99, $380 \mathrm{pCi} / \mathrm{L}$ for gross alpha, and $680 \mathrm{pCi} / \mathrm{L}$ for nonvolatile beta. These radiochemical data are summarized in Table 3. Activity levels for the feedwater used in this study are similar, but consistently lower, than historical data in the Preliminary Engineering Report for the WTU and reported in Serkiz et al. 2000. This is thought to be due to the slow decline in concentrations since the beginning of remediation operations.

Silver and uranium data for column influent are summarized in Table 4. For silver the average concentration is about $9 \mathrm{ppb}$ and for uranium about $1.6 \mathrm{ppm}$. 
Table 3 - Radiochemical Data for F WTU Feedwater (pCi/L)

\begin{tabular}{|c|c|c|c|c|c|c|c|c|}
\hline $\begin{array}{l}\text { Bedvol. } \\
\text { Effluent }\end{array}$ & $\begin{array}{c}\mathrm{I}-129 \\
(\mathrm{pCi} / \mathrm{L})\end{array}$ & \begin{tabular}{|c|} 
Counting \\
Error \\
Std Dev
\end{tabular} & $\begin{array}{c}\text { Tc-99 } \\
(\mathrm{pCi} / \mathrm{L})\end{array}$ & $\begin{array}{c}\text { Countin } \\
\mathrm{g} \\
\text { Error } \\
\text { Std Dev }\end{array}$ & $\begin{array}{c}\text { Gross } \\
\text { Alpha } \\
(\mathrm{pCi} / \mathrm{L})\end{array}$ & $\begin{array}{l}\text { Counting } \\
\text { Error } \\
\text { Std Dev }\end{array}$ & $\begin{array}{c}\text { Nonvolatile } \\
\text { Beta } \\
(\mathrm{pCi} / \mathrm{L})\end{array}$ & $\begin{array}{l}\text { Counting } \\
\text { Error } \\
\text { Std Dev }\end{array}$ \\
\hline 75 & 54.8 & 4.35 & & & & & & \\
\hline 125 & 45.9 & 7.98 & & & & & & \\
\hline 175 & 58 & 10.1 & & & & & & \\
\hline 250 & & & 55 & 6.79 & 394 & 15.9 & 663 & 12.1 \\
\hline 325 & 63.2 & 9.55 & & & & & & \\
\hline 375 & 56.4 & 7.2 & & & & & & \\
\hline 425 & 56.9 & 9.99 & & & & & & \\
\hline 500 & & & 50.4 & 5.88 & 322 & 13.2 & 685 & 12.9 \\
\hline 575 & 58.6 & 3.81 & & & & & & \\
\hline 650 & & & 65.7 & 6.78 & 501 & 34.6 & 738 & 23.2 \\
\hline 725 & 63.7 & 9.33 & & & & & & \\
\hline 800 & & & 81.2 & 8.49 & 371 & 14.1 & 617 & 12.3 \\
\hline 875 & 56.1 & 9.03 & & & & & & \\
\hline 950 & & & 70.1 & 6.88 & 293 & 13.1 & 708 & 13.5 \\
\hline 1025 & 47.4 & 7.44 & & & & & & \\
\hline Average & 56.1 & & 64.48 & & 376.2 & & 682.2 & \\
\hline Std Dev & 5.8 & & 12.3 & & 80.3 & & 45.8 & \\
\hline
\end{tabular}

Table 4 - Elemental Composition Data for F WTU Feedwater (mg/L)

\begin{tabular}{|r|c|c|}
\hline $\begin{array}{r}\text { Bedvol. } \\
\text { Effluent }\end{array}$ & $\mathrm{Ag}$ & $\mathrm{U}$ \\
\hline 100 & 0.0021 & 1.714 \\
\hline 150 & 0.0029 & 1.717 \\
\hline 200 & 0.0018 & 1.700 \\
\hline 250 & 0.0022 & 1.700 \\
\hline 350 & 0.0036 & 1.697 \\
\hline 400 & 0.0039 & 1.704 \\
\hline 450 & 0.0040 & 1.715 \\
\hline 500 & 0.0289 & 1.506 \\
\hline 600 & 0.0160 & 1.520 \\
\hline 650 & 0.0116 & 1.562 \\
\hline 750 & 0.0106 & 1.518 \\
\hline 800 & 0.0115 & 1.521 \\
\hline 900 & 0.0130 & 1.516 \\
\hline 950 & 0.0127 & 1.509 \\
\hline Average & 0.0089 & 1.614 \\
Std Dev & 0.0076 & 0.097 \\
\hline
\end{tabular}




\subsection{Concept 1 - Silver Modified Activated Carbons}

Effluent water quality data for these column studies are presented in Tables 5 and

6 for radiochemical and ICP-ES silver and uranium analyses respectively.

\subsubsection{Effluent I-129 Data}

Data for I-129 activity as a function of bedvolumes of effluent are presented graphically in Figure 6. The performance of the silver modified carbons with actual F WTU feedwater was very good with I-129 breakthrough (as defined by effluent activity of $50 \%$ of the feedwater activity) not being reached for any of these materials during the 1050 bedvolumes duration of this test. Furthermore, none of the column effluent I-129 activities were above the detection limit until after 725 bedvolumes and after this point effluent volume only slightly above the $10 \mathrm{pCi} / \mathrm{L}$ detection limit. At the last data point, the SIAC- $\mathrm{AgCl} 0.05 \%$ showed an increase in I-129 activity to about $20 \mathrm{pCi} / \mathrm{L}$. It is important not to over interpret a single data point, but this may indicate that this material had expended its capacity for I-129 removal as it originally contained only $1 / 20^{\text {th }}$ of the silver in the $1.05 \%$ SIAC.

Contact times in the laboratory were similar to what would be expected for fesd water flow rates under normal plant operation and I-129 removal was achieved with the silver modified carbons, I129 removal kinetics is not expected to be problematic under normal plant flow rate conditions.

In contrast to the silver-modified carbons, the base activated carbon showed breakthrough at about 600 bedvolumes.

\subsubsection{Effluent Tc-99 Data}

Data for Tc-99 activity as a function of bedvolumes of effluent are presented graphically in Figure 7. All carbon materials produced effluent below detection limit over the entire duration of the experiment. The exact mechanism for Tc removal is not known, but is thought to be nonspecific sorption to the activated carbon and/or a reduction of $\mathrm{TcO}_{4}{ }^{-}$anion to $\mathrm{Tc}^{+4}$ cation and subsequent precipitation of an insoluble $\mathrm{Tc}(\mathrm{IV}) \mathrm{O}_{2}$ solid.

\subsubsection{Effluent Gross Alpha/Nonvolatile Beta}

Gross alpha and nonvolatile beta data do not exhibit any major trends for the carbon materials evaluated. The gross alpha data (see Table 5) show removal of alpha activity by up to a factor of 2 for the silver-modified carbons. These observations are consistent with elemental data for uranium (the major alpha contributor) where uranium DF values started at a value of greater than 3 and fell to minimum values of about 1.5 at the end of the experiment (see Table 6). Coupled with the isotope specific analyses for I-129 and Tc-99, this suggests that the silver modified materials are highly specific for the target anions (I-129 and Tc-99).

\subsubsection{Effluent Silver Data}

Hoskins et al. (2002) identified Ag leaching in the absence of iodide from SIAC-Ag(0) under acidic conditions. This was the motivation for producing and testing SIAC-AgCl materials.

Consistent with these previous observations, silver leaching from the SIAC-Ag(0) was significantly greater than that for SIAC-AgCl. In fact, effluent concentrations were as high as $13.9 \mathrm{mg} / \mathrm{L}$, which is above the USEPA's TCLP leachate limit of $5 \mathrm{mg} / \mathrm{L}$. Note that the TCLP extraction limit is for use with the acetic acid TCLP extraction in order to define RCRA 
hazardous material.

In comparison, the maximum silver concentrations observed in effluents from the SIAC-AgCl column effluents were $0.36 \mathrm{mg} / \mathrm{L}$. Maximum concentrations were approximately equal for both the 0.05 and 1.05 percent SIAC-AgCl materials and these data suggest that silver was leached under a solubility control mechanism. For both of the SIAC-AgCl materials, silver concentrations in the effluent rose quickly to maximum concentrations in the first several hundred bedvolumes. In the case of the $1.05 \%$ SIAC- $\mathrm{AgCl}$, the effluent silver concentration remained relatively constant near the maximum concentration through the remainder of the test. In contrast, the $0.05 \%$ SIAC quickly reached a maximum silver concentration and then rapidly declined. Because there was only about $6 \mathrm{mg}$ silver in this column, it is thought that the reduction in silver in the effluent is due to a depletion of silver in the SIAC (note: $20 \mathrm{~L}$ at $0.3 \mathrm{mg} / \mathrm{L}$ would account for leaching of all the silver). 
Table 5 - Radiochemical Data Concept 1 (Silver Modified Carbons)

\begin{tabular}{|c|c|c|c|c|c|c|c|c|c|c|}
\hline \multirow{2}{*}{$\begin{array}{l}\text { Bedvol. } \\
\text { Effluent }\end{array}$} & \multicolumn{2}{|c|}{ Feedwater } & \multicolumn{2}{|c|}{$\begin{array}{l}\text { Base Activated } \\
\text { Carbon }\end{array}$} & \multicolumn{2}{|c|}{$\begin{array}{c}1.05 \% \\
\text { SIAC-Ag(0) }\end{array}$} & \multicolumn{2}{|c|}{$\begin{array}{l}0.05 \% \text { SIAC- } \\
\mathrm{AgCl}\end{array}$} & \multicolumn{2}{|c|}{$\begin{array}{l}1.05 \% \text { SIAC- } \\
\mathrm{AgCl}\end{array}$} \\
\hline & $\begin{array}{l}\mathrm{I}-129 \\
(\mathrm{pCi} / \mathrm{L})\end{array}$ & Std Dev & $\begin{array}{l}\mathrm{I}-129 \\
(\mathrm{pCi} / \mathrm{L})\end{array}$ & Std Dev & $\begin{array}{l}\mathrm{I}-129 \\
(\mathrm{pCi} / \mathrm{L})\end{array}$ & Std Dev & $\begin{array}{l}\mathrm{I}-129 \\
(\mathrm{pCi} / \mathrm{L})\end{array}$ & Std Dev & $\begin{array}{l}\mathrm{I}-129 \\
(\mathrm{pCi} / \mathrm{L})\end{array}$ & Std Dev \\
\hline 75 & 54.8 & 4.35 & 0.823 & 2.50 & 1.28 & 1.32 & 0.0307 & 1.82 & -0.429 & 1.29 \\
\hline 125 & 45.9 & 7.98 & 5.95 & 3.19 & -0.343 & 7.57 & -0.655 & 1.74 & 0.288 & 0.926 \\
\hline 175 & 58.0 & 10.1 & 9.28 & 2.01 & -0.0777 & 0.446 & 0.713 & 0.626 & -0.148 & 0.903 \\
\hline 325 & 63.2 & 9.55 & 20.3 & 4.14 & 0.148 & 1.29 & 0.0973 & 0.963 & 1.41 & 1.69 \\
\hline 375 & 56.4 & 7.2 & 15.7 & 4.71 & -0.185 & 0.862 & 0.302 & 1.85 & 0.432 & 1.20 \\
\hline 425 & 56.9 & 9.99 & 20.4 & 2.06 & -0.0462 & 0.492 & 0.346 & 0.621 & 0.789 & 0.828 \\
\hline 575 & 58.6 & 3.81 & 24.6 & 3.73 & -0.187 & 0.828 & 2.00 & 1.37 & 0.504 & 1.34 \\
\hline 725 & 63.7 & 9.33 & 33.1 & 4.93 & 0.657 & 1.43 & 0.0054 & 0.943 & 0.180 & 0.683 \\
\hline 875 & 56.1 & 9.03 & 23.5 & 5.59 & 7.39 & 1.86 & 0.472 & 0.637 & 0.546 & 1.32 \\
\hline 1025 & 47.4 & 7.44 & 25.1 & 5.22 & -0.0859 & 1.60 & 17.0 & 4.31 & 7.42 & 4.98 \\
\hline \begin{tabular}{|l|} 
Bedvol. \\
Effluent
\end{tabular} & \begin{tabular}{|c|} 
Tc-99 \\
$(\mathrm{pCi} / \mathrm{L})$
\end{tabular} & Std Dev & \begin{tabular}{|c|} 
Tc-99 \\
$(\mathrm{pCi} / \mathrm{L})$
\end{tabular} & Std De & \begin{tabular}{|c|} 
Tc-99 \\
(pCi/L)
\end{tabular} & Std Dev & $\begin{array}{c}\mathrm{Tc}-99 \\
(\mathrm{pCi} / \mathrm{L})\end{array}$ & Std Dev & $\begin{array}{c}\mathrm{Tc}-99 \\
(\mathrm{pCi} / \mathrm{L})\end{array}$ & Std Dev \\
\hline 250 & 55.0 & 6.79 & 3.05 & 3.02 & 0.587 & 2.77 & 0.855 & 2.75 & -0.990 & 2.58 \\
\hline 500 & 50.4 & 5.88 & 3.44 & 3.12 & 0.215 & 2.70 & -0.420 & 2.58 & -2.96 & 2.31 \\
\hline 650 & 65.7 & 6.78 & 4.18 & 3.33 & 0.426 & 3.27 & -1.57 & 2.72 & -1.94 & 2.80 \\
\hline 800 & 81.2 & 8.49 & 4.71 & 3.32 & 0.864 & 3.09 & 3.25 & 3.22 & -3.59 & 12.8 \\
\hline 950 & 70.1 & 6.88 & 5.99 & 3.38 & -0.987 & 2.85 & 2.63 & 3.14 & -2.89 & 2.57 \\
\hline $\begin{array}{l}\text { Bedvol. } \\
\text { Effluent }\end{array}$ & $\begin{array}{c}\text { Gross } \\
\text { Alpha } \\
\text { (pCi/L) }\end{array}$ & Std Dev & $\begin{array}{c}\text { Gross } \\
\text { Alpha } \\
(\mathrm{pCi} / \mathrm{L})\end{array}$ & Std Dev & $\begin{array}{c}\text { Gross } \\
\text { Alpha } \\
(\mathrm{pCi} / \mathrm{L})\end{array}$ & Std Dev & $\begin{array}{c}\text { Gross } \\
\text { Alpha } \\
\text { (pCi/L) }\end{array}$ & Std Dev & $\begin{array}{c}\text { Gross } \\
\text { Alpha } \\
\text { (pCi/L) }\end{array}$ & Std Dev \\
\hline 250 & 394 & 15.9 & 379 & 31.9 & 232 & 6.86 & 248 & 12.8 & 207 & 6.26 \\
\hline 500 & 322 & 13.2 & 436 & 43.2 & 299 & 14.8 & 282 & 13.1 & 244 & 12.8 \\
\hline 650 & 501 & 34.6 & 344 & 13.6 & 272 & 12.4 & 305 & 15.0 & 235 & 12.6 \\
\hline 800 & 371 & 14.1 & 230 & 12.3 & 308 & 14.9 & 275 & 13.2 & 274 & 12.8 \\
\hline 950 & 293 & 13.1 & 288 & 13.1 & 318 & 14.5 & 318 & 13.9 & 296 & 13.0 \\
\hline $\begin{array}{l}\text { Bedvol. } \\
\text { Effluent }\end{array}$ & $\begin{array}{c}\text { Nonvol. } \\
\text { Beta } \\
(\mathrm{pCi} / \mathrm{L})\end{array}$ & Std Dev & $\begin{array}{c}\text { Nonvol. } \\
\text { Beta } \\
(\mathrm{pCi} / \mathrm{L})\end{array}$ & Std Dev & $\begin{array}{c}\text { Nonvol. } \\
\text { Beta } \\
(\mathrm{pCi} / \mathrm{L})\end{array}$ & Std Dev & $\begin{array}{c}\text { Nonvol. } \\
\text { Beta } \\
(\mathrm{pCi} / \mathrm{L})\end{array}$ & Std Dev & $\begin{array}{c}\text { Nonvol. } \\
\text { Beta } \\
(\mathrm{pCi} / \mathrm{L})\end{array}$ & Std Dev \\
\hline 250 & 663 & 12.1 & 742 & 34.1 & 664 & 7.29 & 579 & 11.3 & 638 & 7.10 \\
\hline 500 & 685 & 12.9 & 826 & 46.2 & 634 & 12.0 & 706 & 13.5 & 557 & 11.1 \\
\hline 650 & 738 & 23.2 & 719 & 13.2 & 648 & 12.8 & 618 & 11.9 & 510 & 10.7 \\
\hline 800 & 617 & 12.3 & 529 & 10.9 & 648 & 12.1 & 546 & 13.2 & 535 & 12.8 \\
\hline 950 & 708 & 13.5 & 706 & 13.5 & 608 & 11.6 & 581 & 11.3 & 674 & 13.1 \\
\hline
\end{tabular}


Table 6 - ICP-ES Silver and Uranium Data Concept 1 (Silver-Modified Carbons)

\begin{tabular}{|c|c|c|c|c|c|c|c|c|c|c|c|}
\hline \multirow{2}{*}{$\begin{array}{l}\text { Bedvol. } \\
\text { Effluent }\end{array}$} & \multicolumn{2}{|c|}{ Feedwater } & \multicolumn{3}{|c|}{$1.05 \%$ SIAC- $\operatorname{Ag}(0)$} & \multicolumn{3}{|c|}{$0.05 \%$ SIAC-AgCl } & \multicolumn{3}{|c|}{$1.05 \%$ SIAC-AgCl } \\
\hline & $\begin{array}{c}\mathrm{Ag} \\
(\mathrm{mg} / \mathrm{L})\end{array}$ & \begin{tabular}{|c|}
$\mathbf{U}$ \\
$(\mathrm{mg} / \mathrm{L})$
\end{tabular} & $\begin{array}{c}\mathrm{Ag} \\
(\mathrm{mg} / \mathrm{L}) \\
\end{array}$ & \begin{tabular}{|c|}
$\mathbf{U}$ \\
$(\mathrm{mg} / \mathrm{L})$
\end{tabular} & \begin{tabular}{|c|}
$\mathbf{U}$ DF \\
(Unitless) \\
\end{tabular} & $\begin{array}{c}\mathrm{Ag} \\
(\mathrm{mg} / \mathrm{L})\end{array}$ & $\begin{array}{c}\mathbf{U} \\
(\mathrm{mg} / \mathbf{L}) \\
\end{array}$ & \begin{tabular}{|c|}
$\mathbf{U} \mathbf{D F}$ \\
(Unitless) \\
\end{tabular} & $\begin{array}{c}\mathrm{Ag} \\
(\mathrm{mg} / \mathrm{L})\end{array}$ & $\begin{array}{c}\mathbf{U} \\
(\mathrm{mg} / \mathrm{L})\end{array}$ & $\begin{array}{c}\mathbf{U} \mathbf{D F} \\
\text { (Unitless) } \\
\end{array}$ \\
\hline 100 & 0.0021 & 1.714 & 0.073 & $<0.550$ & $>3.12$ & 0.052 & $<0.550$ & $>3.12$ & 0.036 & $<0.550$ & $>3.12$ \\
\hline 150 & 0.0029 & 1.717 & 0.174 & $<0.550$ & $>3.12$ & 0.365 & $<0.550$ & $>3.12$ & 0.066 & $<0.550$ & $>3.12$ \\
\hline 200 & 0.0018 & 1.700 & 1.42 & $<0.550$ & $>3.09$ & 0.321 & $<0.550$ & $>3.09$ & 0.279 & $<0.550$ & $>3.09$ \\
\hline 250 & 0.0022 & 1.700 & 13.9 & 0.639 & 2.66 & 0.298 & 0.620 & 2.74 & 0.307 & 0.598 & 2.84 \\
\hline 350 & 0.0036 & 1.697 & 13.4 & 0.719 & 2.36 & 0.274 & 0.637 & 2.66 & 0.314 & 0.622 & 2.73 \\
\hline 400 & 0.0039 & 1.704 & 9.69 & 0.714 & 2.39 & 0.262 & 0.610 & 2.79 & 0.324 & 0.640 & 2.66 \\
\hline 450 & 0.0040 & 1.715 & 5.63 & 0.751 & 2.28 & 0.266 & 0.713 & 2.41 & 0.336 & 0.682 & 2.51 \\
\hline 500 & 0.0289 & 1.506 & 1.52 & 0.799 & 1.88 & 0.139 & 0.734 & 2.05 & 0.338 & 0.690 & 2.18 \\
\hline 600 & 0.0160 & 1.520 & 0.855 & 0.787 & 1.93 & 0.079 & 0.746 & 2.04 & 0.338 & 0.887 & 1.71 \\
\hline 650 & 0.0116 & 1.562 & 0.678 & 0.876 & 1.78 & 0.062 & 0.746 & 2.09 & 0.335 & 0.839 & 1.86 \\
\hline 750 & 0.0106 & 1.518 & 0.657 & 0.861 & 1.76 & 0.041 & 0.660 & 2.30 & 0.355 & 0.931 & 1.63 \\
\hline 800 & 0.0115 & 1.521 & 0.670 & 0.790 & 1.93 & 0.040 & 0.775 & 1.96 & 0.343 & 0.875 & 1.74 \\
\hline 900 & 0.0130 & 1.516 & 0.596 & 0.836 & 1.81 & 0.040 & 0.792 & 1.91 & 0.338 & 0.987 & 1.54 \\
\hline 950 & 0.0127 & 1.509 & 0.441 & 0.853 & 1.77 & 0.035 & 0.784 & 1.92 & 0.322 & 0.914 & 1.65 \\
\hline 1050 & NA & NA & 0.358 & 0.840 & 1.79 & 0.014 & 0.814 & 1.84 & NA & NA & \\
\hline
\end{tabular}

$\mathrm{NA}=$ Not Analyzed

Result exceeds $5 \mathrm{mg} / \mathrm{L} \mathrm{Ag} \mathrm{TCLP} \mathrm{Limit}$

\subsubsection{Effluent Uranium Data}

The UIC limit for uranium activity is $50 \mathrm{pCi} / \mathrm{L}$ and the post clarification anion exchange units serve to polish uranium not removed in the precipitation and clarification processes. Therefore, if the post-clarification anion exchange resin were removed in lieu of anion removal in the feedwater, meeting UIC limits for uranium could be problematic if the units received elevated levels of uranium and the feedwater anion exchange units did not remove uranium.

Elemental uranium data collected by ICP-ES for the feedwater and silver-modified carbon column effluent are presented in Table 6. Average feedwater concentrations are approximately $1.6 \mathrm{mg} / \mathrm{L}$. There appears to be an inconsistency, however, between the gross alpha activities and elemental ICP-ES uranium data as $1.6 \mathrm{mg} / \mathrm{L}{ }^{238} \mathrm{U}$ should have an alpha activity of $540 \mathrm{pCi} / \mathrm{L}$ and none of the gross alpha activities measured in the feedwater are that high (see Table 5). Even so, as long as the discrepancy between the two measurements is proportional, DF values can be calculated from the data. Average DF values, assuming all the gross alpha activity is attributable to uranium range from 1.3 to 1.5 whereas DF values calculated from elemental uranium data range from 2.3 to 2.5 . In either case, the silver-modified carbons are likely removing some uranium and the mechanism is thought to be reduction of U(VI) to the generally less soluble and stronger sorbing $\mathrm{U}(\mathrm{IV})$ form.

With these DF values, we can calculate the maximum feed activities the F WTU can accommodate and still achieve the $50 \mathrm{pCi} / \mathrm{L}$ UIC injection limits. Assuming an RO-DF of 50 and a clarifier-DF of 10 (both from F WTU plant data), a DF of 1.3 corresponds to a maximum treatable feedwater activity of $1250 \mathrm{pCi} / \mathrm{L}$ and at a $\mathrm{DF}$ of 2.3 corresponds to $2400 \mathrm{pCi} / \mathrm{L}$. Current 
feedwater activities at the F WTU are on the order of $600 \mathrm{pCi} / \mathrm{L}$ and, therefore, the placement of anion removal at the WTU feed location should still provide adequate uranium removal even with higher uranium activities in the feedwater.

\subsubsection{Solids Analysis}

TCLP was completed on both the original sorbent and after column testing (top $5^{\text {th }}$ of column solid). Additionally, microwave dissolution of the top $5^{\text {th }}$ of the column for the base carbon and the $0.05 \%$ SIAC- $\mathrm{AgCl}$ and individual analyses of five individual sections of the $1.05 \%$ SIAC$\mathrm{Ag}(0)$ and $1.05 \%$ SIAC-AgCl was completed on solids after column testing. These results are summarized in Tables 7 and 8 for the TCLP and microwave dissolution, respectively.

Table 7 - TCLP Silver Data for Silver Modified Carbons

\begin{tabular}{|l|c|}
\hline \multicolumn{1}{|c|}{ Material } & $\begin{array}{c}\text { Unreacted Sorbent } \\
\text { TCLP Ag }(\mathrm{mg} / \mathrm{L})\end{array}$ \\
\hline $0.05 \%$ SIAC-Ag(0) & NA \\
\hline $1.05 \%$ SIAC-Ag(0) & NA \\
\hline $0.05 \%$ SIAC $(\mathrm{AgCl})$ & $<0.3$ \\
\hline $1.05 \%$ SIAC $(\mathrm{AgCl})$ & $<0.3$ \\
\hline
\end{tabular}

Notes: NA $=$ Not Analyzed; post column results are from the top $5^{\text {th }}$ (outlet) of column 
Table 8 - Ag and U Post Column Test Data for Silver Modified Carbons

\begin{tabular}{|c|c|c|c|c|c|}
\hline Material & $\begin{array}{l}\text { Sample } \\
\text { Location }\end{array}$ & $\begin{array}{c}\text { Ag TCLP } \\
\text { Extract } \\
(\mathrm{mg} / \mathrm{L})\end{array}$ & $\begin{array}{l}\text { Ag Digest } \\
\text { ( } \mu \mathrm{g} / \mathrm{g} \text { solid })\end{array}$ & $\begin{array}{l}\text { U TCLP } \\
\text { Extract } \\
(\mathrm{mg} / \mathrm{L})\end{array}$ & $\begin{array}{c}\text { U Digest } \\
\text { ( } \mu \mathrm{g} / \mathrm{g} \text { solid })\end{array}$ \\
\hline Base Carbon & Top $5^{\text {th }}$ & 0.219 & 24.2 & $<5.00$ & $<439$ \\
\hline \multirow[t]{5}{*}{$1.05 \%$ SIAC-Ag(0) } & Top $5^{\text {th }}$ & 10.2 & 2630 & $<5.00$ & $<490$ \\
\hline & $2 \mathrm{nd} 5^{\text {th }}$ & NA & 2690 & NA & $<451$ \\
\hline & $3 \mathrm{rd} \mathrm{5}^{\text {th }}$ & NA & 2720 & NA & $<484$ \\
\hline & 4 th $5^{\text {th }}$ & NA & 2200 & NA & $<482$ \\
\hline & Bottom $5^{\text {th }}$ & NA & 2020 & NA & $<463$ \\
\hline $0.05 \%$ SIAC- $\mathrm{AgCl}$ & Top $5^{\text {th }}$ & $<0.05$ & 54.4 & $<0.03$ & $<215$ \\
\hline \multirow[t]{5}{*}{$1.05 \%$ SIAC-AgCl } & Top $5^{\text {th }}$ & 0.113 & 956 & $<0.03$ & 269 \\
\hline & 2 nd $5^{\text {th }}$ & NA & 428 & NA & $<489$ \\
\hline & $3 \mathrm{rd} 5^{\text {th }}$ & NA & 635 & NA & $<455$ \\
\hline & 4 th $5^{\text {th }}$ & NA & 907 & NA & $<455$ \\
\hline & Bottom $5^{\text {th }}$ & NA & 1100 & NA & $<484$ \\
\hline
\end{tabular}

NA $=$ Not Analyzed

Result exceeds $5 \mathrm{mg} / \mathrm{L} \mathrm{Ag} \mathrm{TCLP} \mathrm{Limit}$

Of the modified carbons only one, the $1.05 \%$ SIAC-Ag(0) after the column testing, leached silver at concentrations greater than the silver TCLP limit of $5 \mathrm{mg} / \mathrm{L}$. The digestion concentrations for silver were greatest in the $\operatorname{SIAC}-\operatorname{Ag}(0)$ and were relatively constant over the length of the column. Due to problems with $\mathrm{AgCl}(\mathrm{s})$ digestion, the SIAC-AgCl sample is more difficult to accurately analyze. Therefore, differences observed between solids concentrations of the SIAC$\mathrm{Ag}(0)$ and SIAC-AgCl may be due to problems in the digestion process rather than in actual silver concentration. The initial silver concentrations between these two materials have been reported to be within 10 percent (Cumbie, 2002) and higher column effluent concentrations of $\mathrm{Ag}$ were observed for the SIAC-Ag(0). The higher silver concentrations in the $\operatorname{SIAC}-\operatorname{Ag}(0)$ are, therefore, not consistent with the other observations.

\subsection{Concept 2 - Concurrent I-129/Mercury Removal}

Effluent water quality data for these column studies are presented in Table 9 for radiochemical analyses.

\subsubsection{Effluent I-129 Data}

I-129 data for this concept indicate that there was no significant removal with either the GT-73 resin or GT-73 resin pretreated with mercuric nitrate. Because data on ETF GT-73 waste suggests an association between I-129 and Hg levels, it is thought that this reaction is kinetically very slow and that it is only over long time periods (timeframe of years) that the reaction between mercury and iodine becomes important.

\subsubsection{Effluent Tc-99 Data}

No significant Tc-99 reduction was observed for this concept. 


\subsubsection{Gross Alpha/Nonvolatile Beta}

There is some gross alpha and nonvolatile beta removal although the decontamination factors are low. This is likely due to removal of cations contributing to total alpha (e.g., uranium) and beta (e.g., Sr).

\subsubsection{Solids Analysis}

Because this concept for anion removal was ineffective, no analysis of the solids data is included. 
Table 9 - Radiochemical Data Concept 2

\begin{tabular}{|c|c|c|c|c|c|c|}
\hline \multirow[b]{2}{*}{$\begin{array}{l}\text { Bedvol. } \\
\text { Effluent }\end{array}$} & \multicolumn{2}{|c|}{ Feedwater } & \multicolumn{2}{|c|}{ GT-73 } & \multicolumn{2}{|c|}{$\begin{array}{c}\text { GT-73 Pretreated } \\
\text { w/Hg }\end{array}$} \\
\hline & $\begin{array}{c}\text { I-129 } \\
(\mathrm{pCi} / \mathrm{L})\end{array}$ & Std Dev & $\begin{array}{c}\mathrm{I}-129 \\
(\mathrm{pCi} / \mathrm{L})\end{array}$ & Std Dev & $\begin{array}{c}\text { I-129 } \\
(\mathrm{pCi} / \mathrm{L})\end{array}$ & Std Dev \\
\hline 75 & 54.8 & 4.35 & 46.9 & 7.58 & 52.7 & 5.76 \\
\hline 125 & 45.9 & 7.98 & 54.6 & 5.14 & 49.4 & 8.64 \\
\hline 175 & 58.0 & 10.1 & 54.9 & 5.19 & 53.3 & 8.6 \\
\hline 325 & 63.2 & 9.55 & 50.0 & 8.50 & 49.1 & 9.91 \\
\hline 375 & 56.4 & 7.20 & 58.3 & 9.08 & 56.9 & 5.76 \\
\hline 425 & 56.9 & 9.99 & 65.6 & 11.3 & 46.8 & 8.73 \\
\hline 575 & 58.6 & 3.81 & 62.4 & 9.04 & 59.0 & 8.99 \\
\hline 725 & 63.7 & 9.33 & 56.6 & 4.27 & 56.7 & 9.06 \\
\hline 875 & 56.1 & 9.03 & 59.7 & 4.23 & 60.8 & 10.1 \\
\hline 1025 & 47.4 & 7.44 & 56.6 & 8.74 & 57.5 & 8.74 \\
\hline \begin{tabular}{|l} 
Bedvol. \\
Effluent
\end{tabular} & $\begin{array}{c}\text { Tc-99 } \\
(p C i / L)\end{array}$ & Std Dev & $\begin{array}{c}\text { Tc-99 } \\
\text { (pCi/L) }\end{array}$ & Std Dev & $\begin{array}{c}\text { Tc-99 } \\
\text { (pCi/L) }\end{array}$ & Std Dev \\
\hline 250 & 55.0 & 6.79 & 46.0 & 5.71 & 47.0 & 5.93 \\
\hline 500 & 50.4 & 5.88 & 47.6 & 5.80 & 42.7 & 5.49 \\
\hline 650 & 65.7 & 6.78 & 59.0 & 6.56 & 46.9 & 5.70 \\
\hline 800 & 81.2 & 8.49 & 55.3 & 6.44 & 60.7 & 6.62 \\
\hline 950 & 70.1 & 6.88 & 59.8 & 6.77 & 59.1 & 6.51 \\
\hline \begin{tabular}{|l} 
Bedvol. \\
Effluent
\end{tabular} & $\begin{array}{c}\text { Gross } \\
\text { Alpha } \\
(\mathrm{pCi} / \mathbf{L})\end{array}$ & Std Dev & $\begin{array}{c}\text { Gross } \\
\text { Alpha } \\
(\mathbf{p C i} / \mathbf{L})\end{array}$ & Std Dev & $\begin{array}{c}\text { Gross } \\
\text { Alpha } \\
(\mathbf{p C i} / \mathbf{L})\end{array}$ & Std Dev \\
\hline 250 & 394 & 15.9 & 45.2 & 6.59 & NA & $\mathrm{NA}$ \\
\hline 500 & 322 & 13.2 & 157 & 11.1 & 149 & 9.40 \\
\hline 650 & 501 & 34.6 & 159 & 10.9 & 170 & 9.99 \\
\hline 800 & 371 & 14.1 & 206 & 11.6 & 179 & 12.1 \\
\hline 950 & 293 & 13.1 & 190 & 10.7 & 233 & 13.0 \\
\hline \begin{tabular}{|l} 
Bedvol. \\
Effluent
\end{tabular} & $\begin{array}{c}\text { Nonvol. } \\
\text { Beta } \\
(\mathrm{pCi} / \mathrm{L})\end{array}$ & Std Dev & $\begin{array}{c}\text { Nonvol. } \\
\text { Beta } \\
(\mathrm{pCi} / \mathrm{L})\end{array}$ & Std Dev & $\begin{array}{c}\text { Nonvol. } \\
\text { Beta } \\
(\mathrm{pCi} / \mathbf{L}) \\
\end{array}$ & Std Dev \\
\hline 250 & 663 & 12.1 & 355 & 8.93 & $\mathrm{NA}$ & NA \\
\hline 500 & 685 & 12.9 & 589 & 15.0 & 598 & 12.4 \\
\hline 650 & 738 & 23.2 & 531 & 10.9 & 599 & 12.0 \\
\hline 800 & 617 & 12.3 & 522 & 11.6 & 514 & 10.8 \\
\hline 950 & 708 & 13.5 & 555 & 11.6 & 565 & 11.3 \\
\hline
\end{tabular}




\subsection{Concept 3 - Screening of Commercially Available Anion Resins}

Effluent water quality data for these column studies are presented in Table 10 for radiochemical analyses. Because the WBG-30 resin was largely ineffective in the removal of I-129, further elemental analyses were only completed for the SIR-1200 column effluent. ICP-ES uranium column effluent data are summarized in Table 11.

As previously stated, the intent of this concept is to reduce anion exchange resin costs and to evaluate moving the location of anion removal to the beginning of the WTU process. The potential advantages of moving anion exchange to the head of the process are to reduce competitive anion effects associated with $\mathrm{pH}$ adjustment during the precipitation/flocculation and to reduce or eliminate I-129 from large volume waste streams (i.e., filtercake and postclarification ion exchange resin).

\subsubsection{Effluent I-129 Data}

Data for I-129 as a function of bedvolumes of effluent are presented in Figure 8. These data show that the SIR-1200 resin was effective in removing I-129 from F WTU feedwater over the duration of testing. The DF for this resin is about 5 and is relatively constant over the test period. This DF is slightly lower than observed for the silver-modified carbons. The fact that breakthrough for this resin was not observed over the duration of the test suggests that the capacity for this resin was not exhausted.

I-129 DF values for WBG-30 were lower than the SIR-1200 ranging from about 3 to less than 2 and continually increased over the duration of the test.

\subsubsection{Effluent Tc-99 Data}

Data for Tc-99 as a function of bedvolumes of effluent are presented in Figure 9. As with I-129, the SIR-1200 performed better for Tc-99 removal than WBG-30 resin. DF values for SIR-1200 were on the order of 10 and did not increase significantly over the test. 
Table 10 - Radiochemical Data Concept 3 (Commercial Anion Resin)

\begin{tabular}{|c|c|c|c|c|c|c|}
\hline \multirow[b]{2}{*}{$\begin{array}{l}\text { Bedvol. } \\
\text { Effluent }\end{array}$} & \multicolumn{2}{|c|}{ Feedwater } & \multicolumn{2}{|c|}{ SIR-1200 } & \multicolumn{2}{|c|}{ WBG-30 } \\
\hline & \begin{tabular}{|l|}
$\mathrm{I}-129$ \\
$(\mathrm{pC} \mathbf{i} / \mathrm{L})$
\end{tabular} & Std Dev & $\begin{array}{l}\mathrm{I}-129 \\
(\mathrm{pCi} / \mathrm{L})\end{array}$ & Std Dev & $\begin{array}{l}\mathrm{I}-129 \\
(\mathrm{pCi} / \mathrm{L})\end{array}$ & Std Dev \\
\hline 75 & 54.8 & 4.35 & 5.37 & 2.29 & 21.7 & 3.55 \\
\hline 125 & 45.9 & 7.98 & 9.41 & 3.13 & 17.4 & 3.57 \\
\hline 175 & 58.0 & 10.1 & 10.0 & 2.58 & 27.9 & 4.90 \\
\hline 325 & 63.2 & 9.55 & 7.90 & 3.65 & 26.5 & 5.61 \\
\hline 375 & 56.4 & 7.20 & 10.1 & 2.87 & 28.4 & 4.44 \\
\hline 425 & 56.9 & 9.99 & 7.27 & 2.48 & 29.8 & 5.39 \\
\hline 575 & 58.6 & 3.81 & 9.80 & 2.41 & 28.4 & 5.55 \\
\hline 725 & 63.7 & 9.33 & 10.9 & 3.19 & 38.8 & 7.03 \\
\hline 875 & 56.1 & 9.03 & 9.89 & 2.34 & 41.2 & 3.70 \\
\hline 1025 & 47.4 & 7.44 & 11.5 & 2.77 & 35.3 & 5.51 \\
\hline \begin{tabular}{|l} 
Bedvol. \\
Effluent
\end{tabular} & \begin{tabular}{|c|} 
Tc-99 \\
(pCi/L)
\end{tabular} & Std Dev & $\begin{array}{c}\text { Tc-99 } \\
\text { (pCi/L) }\end{array}$ & Std Dev & \begin{tabular}{|c|} 
Tc-99 \\
$(\mathrm{pCi} / \mathrm{L})$ \\
\end{tabular} & Std Dev \\
\hline 250 & 55.0 & 6.79 & 2.60 & 2.96 & 12.5 & 3.87 \\
\hline 500 & 50.4 & 5.88 & 4.70 & 3.11 & 14.6 & 4.17 \\
\hline 650 & 65.7 & 6.78 & 4.90 & 3.63 & 19.6 & 4.47 \\
\hline 800 & 81.2 & 8.49 & 11.0 & 4.05 & 24.7 & 4.90 \\
\hline 950 & 70.1 & 6.88 & 3.93 & 3.43 & 27.7 & 4.84 \\
\hline $\begin{array}{l}\text { Bedvol. } \\
\text { Effluent }\end{array}$ & $\begin{array}{c}\text { Gross } \\
\text { Alpha } \\
(\mathrm{pCi} / \mathrm{L})\end{array}$ & Std Dev & $\begin{array}{c}\text { Gross } \\
\text { Alpha } \\
\text { (pCi/L) }\end{array}$ & Std Dev & $\begin{array}{c}\text { Gross } \\
\text { Alpha } \\
\text { (pCi/L) }\end{array}$ & Std Dev \\
\hline 250 & 394 & 15.9 & 351 & 15.4 & 133 & 8.97 \\
\hline 500 & 322 & 13.2 & 343 & 13.6 & 118 & 8.44 \\
\hline 650 & 501 & 34.6 & 350 & 13.7 & 161 & 10.6 \\
\hline 800 & 371 & 14.1 & 333 & 13.8 & 212 & 11.1 \\
\hline 950 & 293 & 13.1 & 338 & 13.6 & 256 & 12.8 \\
\hline $\begin{array}{l}\text { Bedvol. } \\
\text { Effluent }\end{array}$ & $\begin{array}{c}\text { Nonvol. } \\
\text { Beta } \\
(\mathrm{pCi} / \mathrm{L})\end{array}$ & Std Dev & $\begin{array}{c}\text { Nonvol. } \\
\text { Beta } \\
(\mathrm{pCi} / \mathrm{L})\end{array}$ & Std Dev & $\begin{array}{c}\text { Nonvol. } \\
\text { Beta } \\
(\mathrm{pCi} / \mathbf{L})\end{array}$ & Std Dev \\
\hline 250 & 663 & 12.1 & 622 & 11.8 & 591 & 12.6 \\
\hline 500 & 685 & 12.9 & 678 & 13.1 & 571 & 11.7 \\
\hline 650 & 738 & 23.2 & 620 & 12.1 & 593 & 11.4 \\
\hline 800 & 617 & 12.3 & 709 & 13.3 & 669 & 12.8 \\
\hline 950 & 708 & 13.5 & 630 & 12.3 & 700 & 13.4 \\
\hline
\end{tabular}




\subsubsection{Gross Alpha/Nonvolatile Beta}

Gross alpha and nonvolatile beta data do not exhibit any obvious systematic trends for the SIR1200 anion resin. Coupled with the isotope specific analyses for I-129 and Tc-99, this suggests that this resin is highly specific for the target anions (I-129 and Tc-99). The WBG-30 resin initially removed alpha activity, but nonvolatile beta reduction was not observed.

\subsubsection{Effluent Uranium Data}

Uranium DF data for SIR-1200 are contained in Table 11. DF values are similar to those obtained for the silver-modified carbon with an average value of 2.0. Unfortunately, the first three samples of column effluent were lost when the project was suspended at the beginning of FY'02 and these samples would be expected to have higher DF values than those later in the column experiment. The loss of these samples is thought to have slightly lowered the average DF reported in this work. Even with a DF of 2, however, this DF is calculated to meet the $50 \mathrm{pCi} / \mathrm{L} \mathrm{UIC}$ injection limit at an influent activity as high as $2100 \mathrm{pCi} / \mathrm{L}$.

\subsubsection{Solids Analysis}

TCLP was completed after column testing (top $5^{\text {th }}$ of column solid) and the extract analyzed for selected RCRA metals and uranium. Additionally, microwave dissolution of the top 5th of the column and these results are summarized in Table 12 .

Table 11 - ICP-ES Uranium Data SIR1200

\begin{tabular}{|r|c|c|c|}
\cline { 2 - 4 } \multicolumn{1}{c|}{} & Feedwater & \multicolumn{2}{c|}{ SIR1200 } \\
\hline $\begin{array}{r}\text { Bedvol. } \\
\text { Effluent }\end{array}$ & $\begin{array}{c}\text { U } \\
\text { (mg/L) }\end{array}$ & $\begin{array}{c}\mathbf{U} \\
\text { (mg/L) }\end{array}$ & $\begin{array}{c}\text { U DF } \\
\text { (Unitless) }\end{array}$ \\
\hline 100 & 1.714 & NA & NA \\
\hline 150 & 1.717 & NA & NA \\
\hline 200 & 1.700 & NA & NA \\
\hline 250 & 1.700 & 0.746 & 2.28 \\
\hline 350 & 1.697 & 0.736 & 2.31 \\
\hline 400 & 1.704 & 0.754 & 2.26 \\
\hline 450 & 1.715 & 0.706 & 2.43 \\
\hline 500 & 1.506 & 1.309 & 1.15 \\
\hline 600 & 1.520 & 0.730 & 2.08 \\
\hline 650 & 1.562 & 0.725 & 2.15 \\
\hline 750 & 1.518 & 0.792 & 1.92 \\
\hline 800 & 1.521 & 0.730 & 2.08 \\
\hline 900 & 1.516 & 0.795 & 1.91 \\
\hline 950 & 1.509 & 0.789 & 1.91 \\
\hline
\end{tabular}

$\mathrm{NA}=$ Not Analyzed 
Table 12 -U Post Column Test Data for Commercially Available Resins

\begin{tabular}{|l|l|c|c|}
\hline \multicolumn{1}{|c|}{ Material } & $\begin{array}{c}\text { Sample } \\
\text { Location }\end{array}$ & $\begin{array}{c}\text { U TCLP } \\
\text { Extract } \\
(\mathrm{mg} / \mathrm{L})\end{array}$ & $\begin{array}{c}\text { U Digest } \\
(\mu \mathrm{g} / \mathrm{g} \text { solid })\end{array}$ \\
\hline SIR 1200 & Top 5 & $<0.77$ & $<224$ \\
\hline WBG-30 & Top 5 & $<0.77$ & 395 \\
\hline
\end{tabular}

\section{Conclusions and Recommendations}

This study examined the feasibility of anion exchange (I-129 and Tc-99 removal) on feedwater to the F-Area WTU. This approach represents a significant departure from the current process configuration in which anion exchange takes place after iron chloride addition, neutralization, and clarification.

The potential advantages of moving anion exchange to the head of the process are to reduce competitive anion effects associated with $\mathrm{pH}$ adjustment during the precipitation and flocculation processes and to reduce or eliminate I-129 from large volume waste streams (i.e., filtercake and post-clarification ion exchange resin).

At the F-Area WTU, process history shows anion breakthrough at approximately 600 bedvolumes of processed feedwater (approximately 4.3 days of continuous operation under full-flow conditions). In this laboratory study, breakthrough was not observed for any of the silver modified carbons as well as the SIR 1200 resin at 1050 bedvolumes (equivalent to approximately 8 days of plant operations). All silver-modified carbons and the commercially available SIR1200 anion resin were effective in removal of I-129 and Tc-99 from the F-Area WTU feedwater. Within these effective materials, the silver modified carbons reduced I-129 to below detection limit over almost the entire duration of the test and exhibited DF values that were somewhat higher than the SIR-1200 resin. Both the silver modified carbons and SIR-1200 resin reduced Tc99 in the feedwater to below detection limit (c. 8 pCi/L).

Although the uranium DF values for the silver-modified carbons and SIR-1200 were small, on the order of 2, this DF should be sufficient to achieve the UIC limits even without post-clarification uranium removal. Given the apparent inconsistency between the gross alpha and ICP-ES data, uranium DF values for these materials should be confirmed prior to any full-scale implementation.

TCLP testing indicates that the secondary waste for the AgCl-modified carbons and SIR-1200 resin would not be RCRA characteristically hazardous. The SIAC-Ag(0) material, however, exhibited elevated silver leaching and a silver TCLP extract concentration in excess of the $5 \mathrm{mg} / \mathrm{L}$ limit for a RCRA characteristic waste.

Because of the solubility control mechanism for $\mathrm{AgI}(\mathrm{s})$ for the $\mathrm{AgCl}$-modified carbons, it is anticipated that I-129 leaching will be lower for these materials than for the SIR-1200. If these materials were put into use, then I-129 and Tc-99 leaching $\mathrm{K}_{\mathrm{d}}$ values would need to be generated to confirm the leaching behavior of the secondary waste.

Concurrent removal of mercury and I-129 was ineffective for separation of I-129 from F WTU feedwater. It is thought that this reaction is kinetically very slow and that it is only over long time periods (timeframe of years) that the reaction between $\mathrm{Hg}$ and I becomes important. 
Given the effectiveness of the silver-modified carbons and SIR-1200, pilot testing of a subset of these materials is recommended. Of these materials, the higher silver content $(1.05 \% \mathrm{Ag})$ silver chloride carbon and SIR-1200 would be the logical choices. The SIR-1200 is commercially available whereas the silver chloride carbon would have to be produced by a specialty activated carbon manufacturer. During any pilot-scale testing, the following data should be collected:

- Complete breakthrough of I-129 and Tc-99;

- Uranium DF values;

- I-129, Tc-99, U, and RCRA metal leaching (both trench leachate and TCLP). 


\section{References}

Allison, J. D.; Brown, D. S.; Gradac, K. J. MINTEQA2/PRODEFA2, A Geochemical Assessment Model for Environmental Systems: Version 3.0 Users Manual. Washington, D. C.: U. S. Government Printing Office. EPA/600/3-91/021; 1991.

Butcher, B. T. Email on Secondary waste disposal costs dated 7/9/02. 2002

Cumbie, E. (2002) "Removal and Sequestration of Iodide From DOE Waste Streams Using Silver Chloride Impregnated Activated Carbon," M.Sc. Thesis. Clemson University, Clemson, SC.

Hoskins, J., Karanfil, T., and Serkiz, S. M. Sequestration of Iodide Using Silver Impregnated Activated Carbon. Environmental Science and Technology, 36 pp. 784-789, 2002.

Kanzleiter, J. P., F-AREA WTU Operational Testing of RESINTECH SIR-1200 Anion Resin TEST PLAN, WSRC-RP-2001-4026, REV. 0. 2001.

Kaplan, D. I., Serkiz, S. M., and Bell, N. C. I-129 Desorption from SRS Water Treatment Media From the Effluent Treatment Facility and the F-Area Groundwater Treatment Facility. WSRC-TR-99-00270. Westinghouse Savannah River Company, Aiken, SC, 1999.

Lindsay, W. L. Chemical Equilibria in Soils. Wiley-Interscience, New York. 1979.

Monson, P. R., N. C. Bell, and S. M. Serkiz. 2000. Evaluation of Selective Ion Exchange Resins for Removal Of Mercury From the H-Area Water Treatment Unit (U) (48 pp.). WSRC-TR-200000109 Rev. 0. Westinghouse Savannah River Company, Aiken, SC.

Serkiz S. M. and Reboul S. H. 1999. F- and H-Area Seepage Basins Water Treatment System Process Optimization and Alternative Chemistry Ion Exchange/Sorbent Material Screening Clearwell Overflow Study (U). WSRC-TR-99-00020. Westinghouse Savannah River Company, Aiken, SC.

Serkiz S. M., Reboul S. H., Bell N. C., Kanzleiter J. P., Bohrer S. R., Lovekamp J. M., and Faulk G. W. Reengineering Water Treatment Units for Removal of Sr-90, I-129, Tc-99, and Uranium From Contaminated Groundwater at the DOE's Savannah River Site. Presented at the Waste Management '00 Symposium. Tucson, AZ, February 26- March 2, 2000.

Stumm W. and Morgan, J.J. Aquatic Chemistry. Wiley \& Sons, New York. 1995. 


\section{Figures}

Figure 1 - F WTU Process Schematic

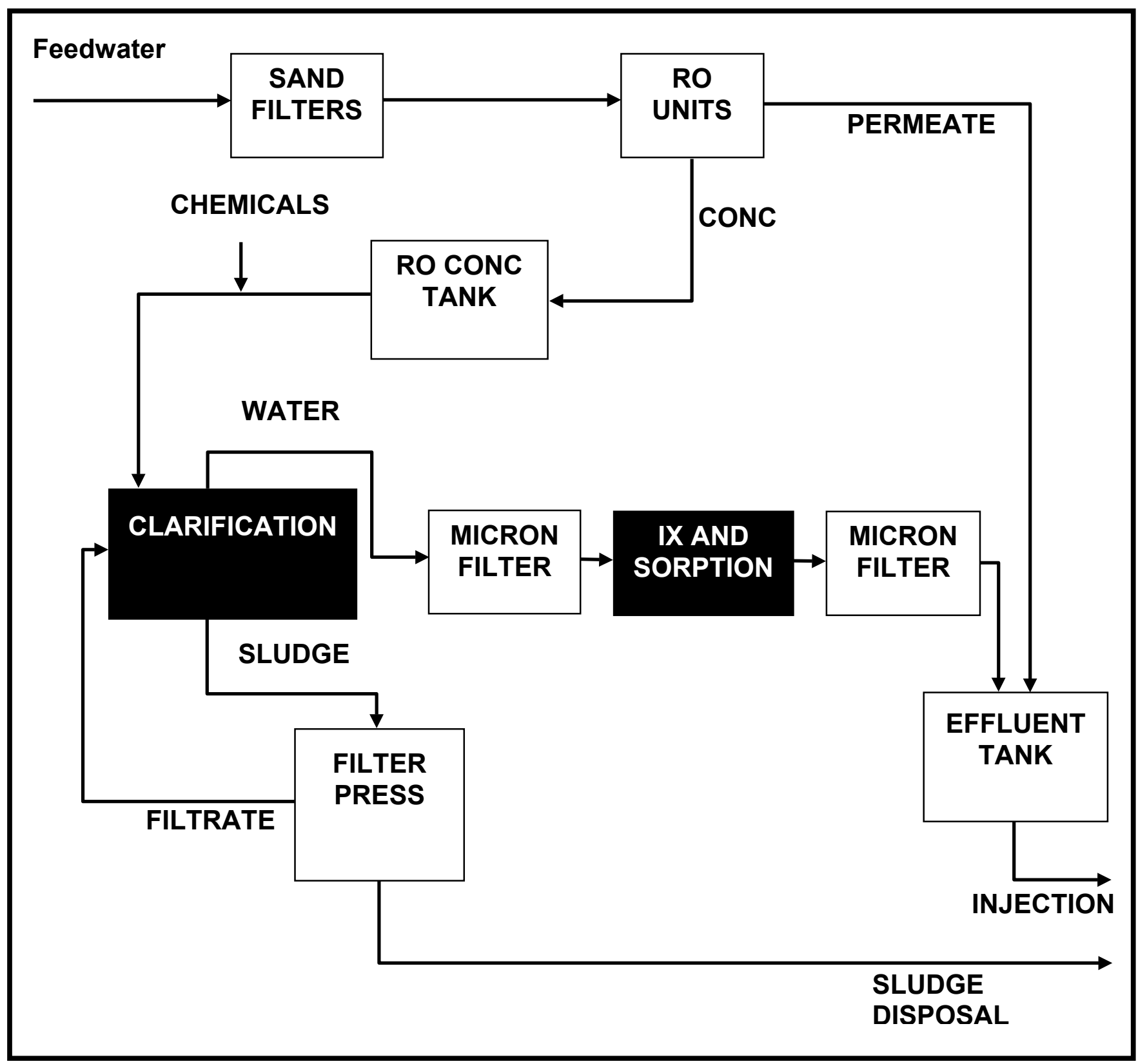




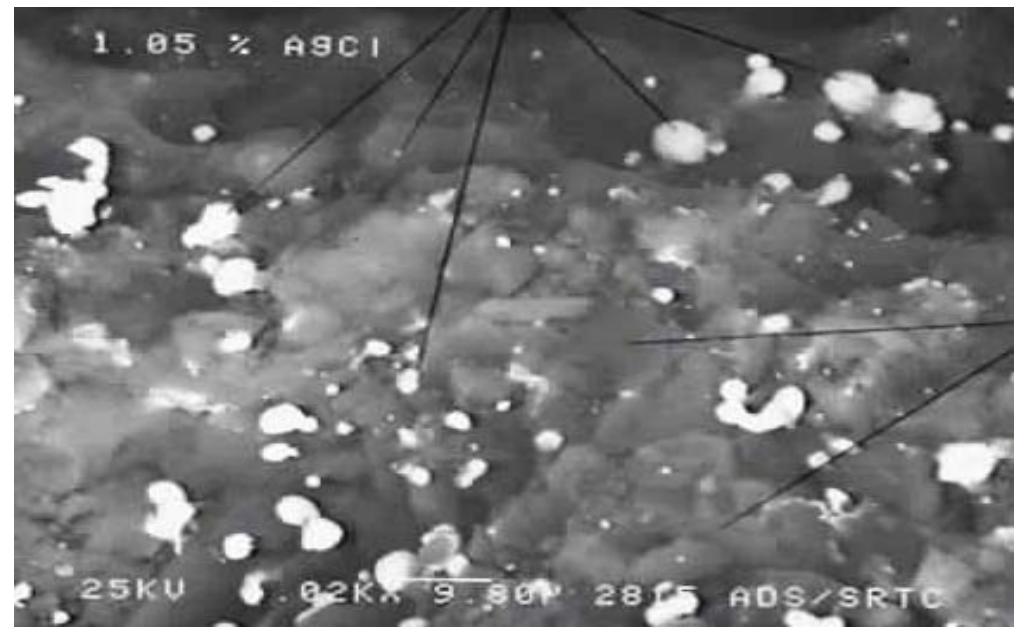

Figure 2 - SEM of AgCl SIAC (2000X Magnification).

Figure 3 - EDX of $\mathrm{AgCl}$ SIAC.

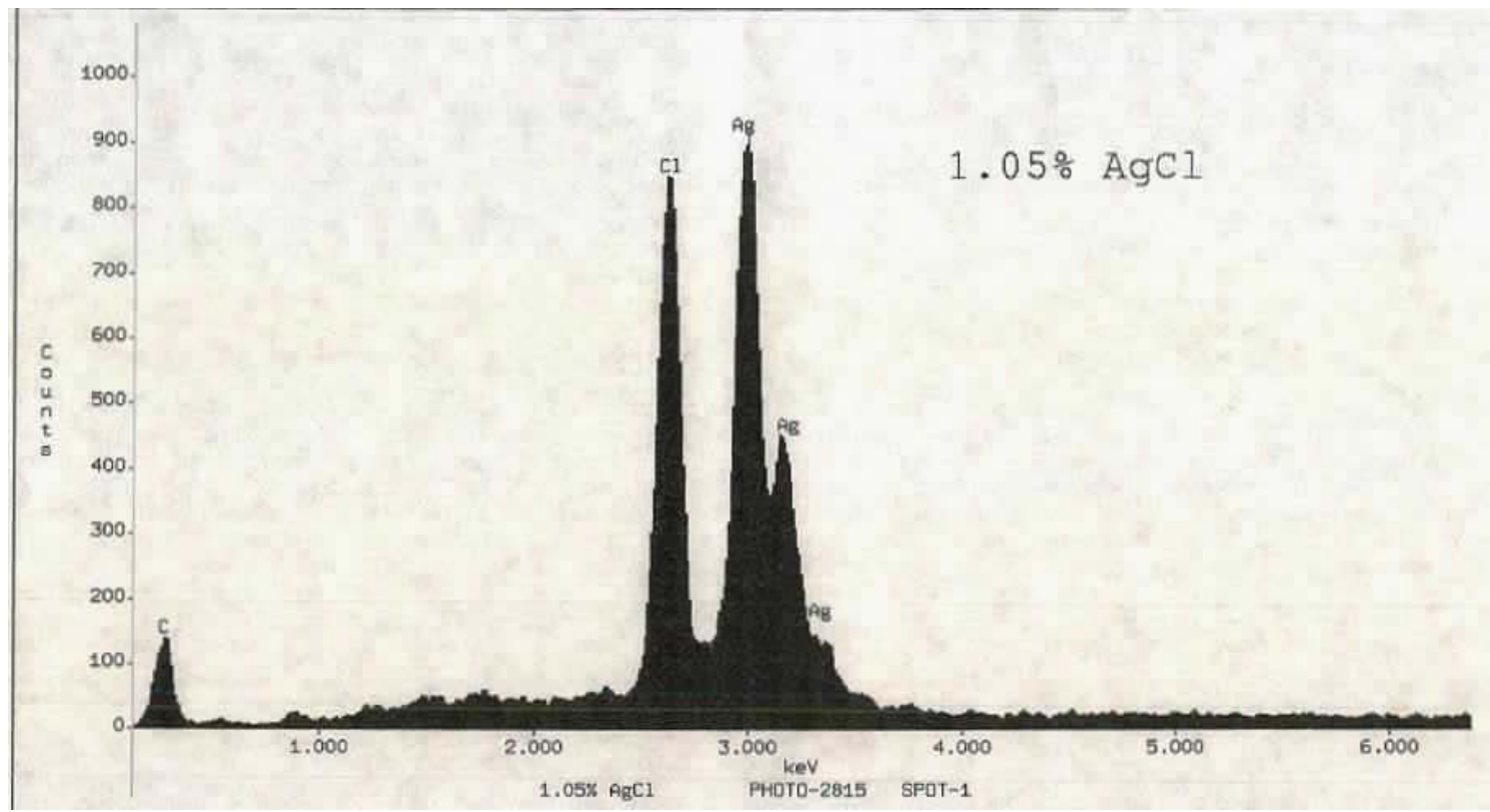


Figure 4 - Schematic of Experimental Setup.

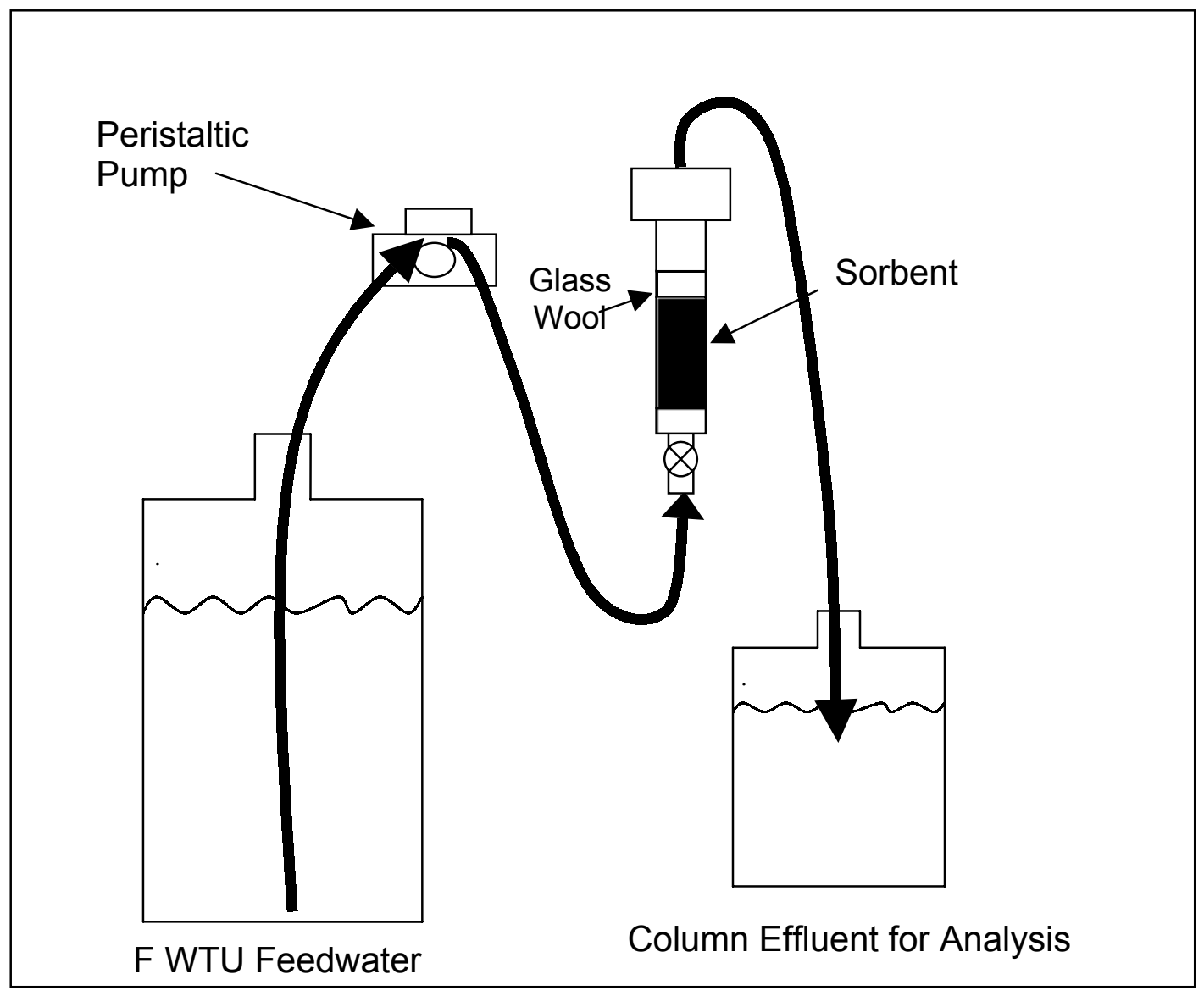


Figure 5 - Photographs of Experimental Setup.
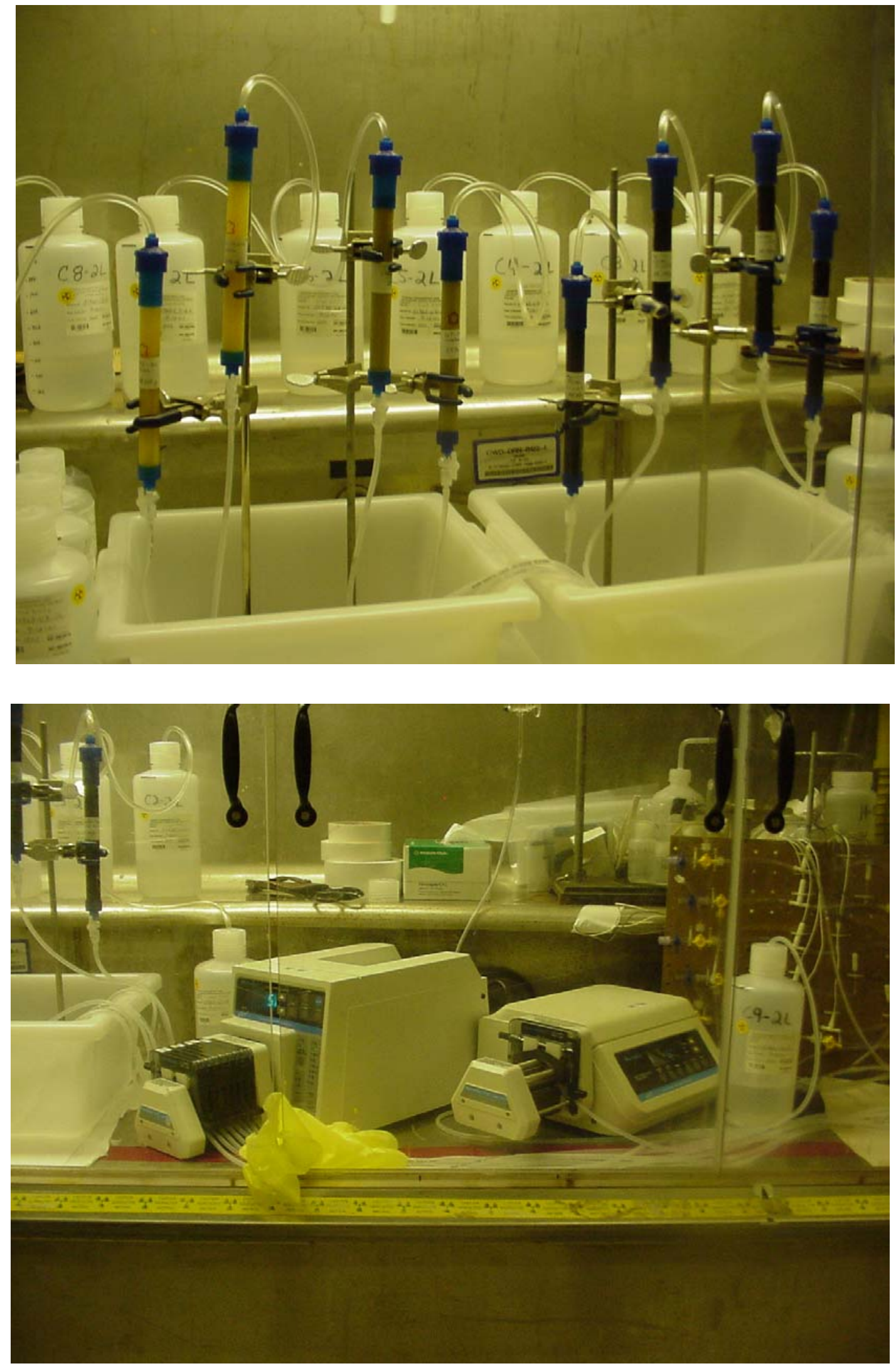

WSRC-TR-2002-00435

Page 30 of 35 
Figure 6 - I-129 Effluent Activity for Concept 1 (Silver Modified Carbons).

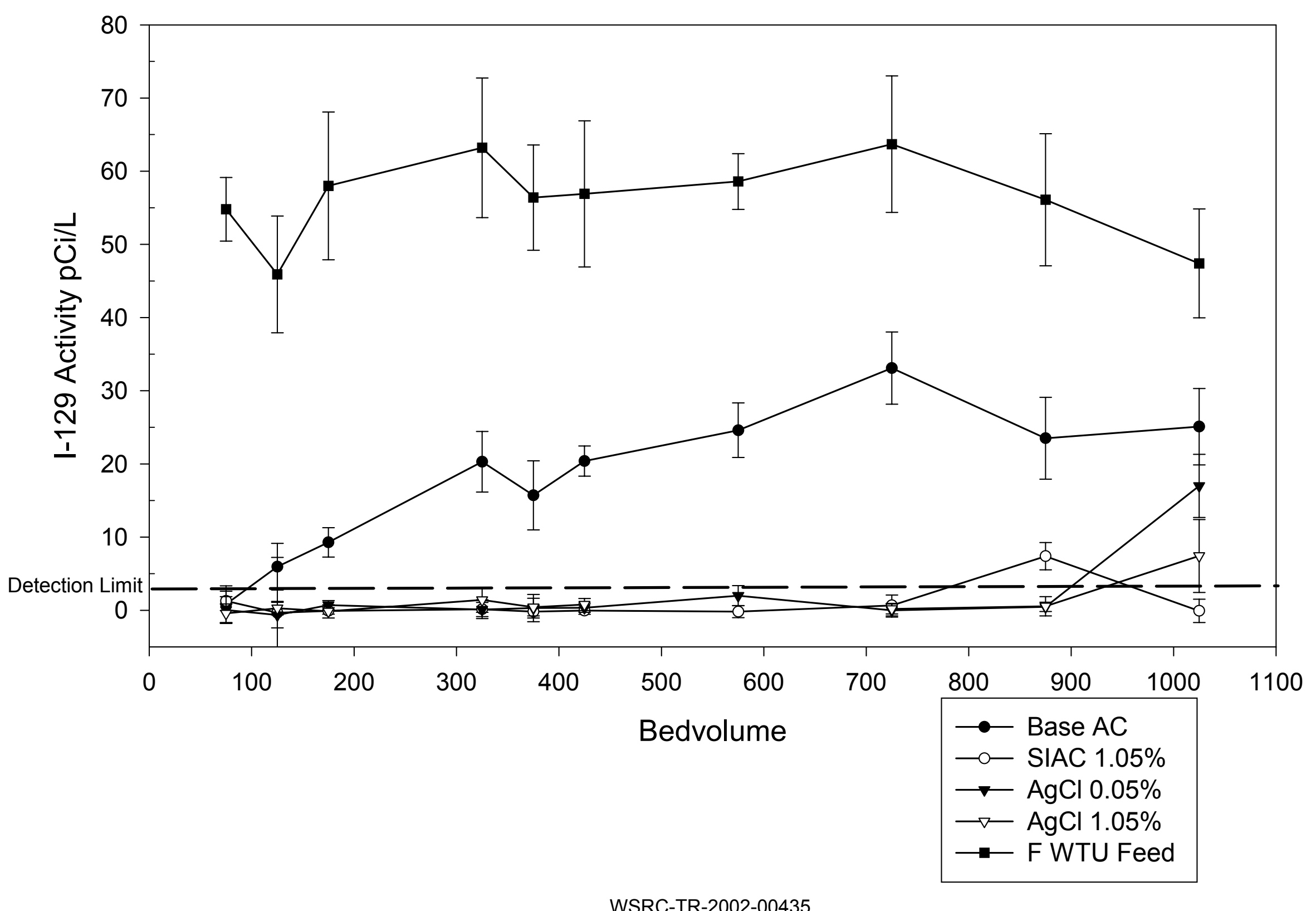

WSRC-TR-2002-00435

Page 31 of 35 
Figure 7 - Tc-99 Effluent Activity for Concept 1 (Silver Modified Carbons).

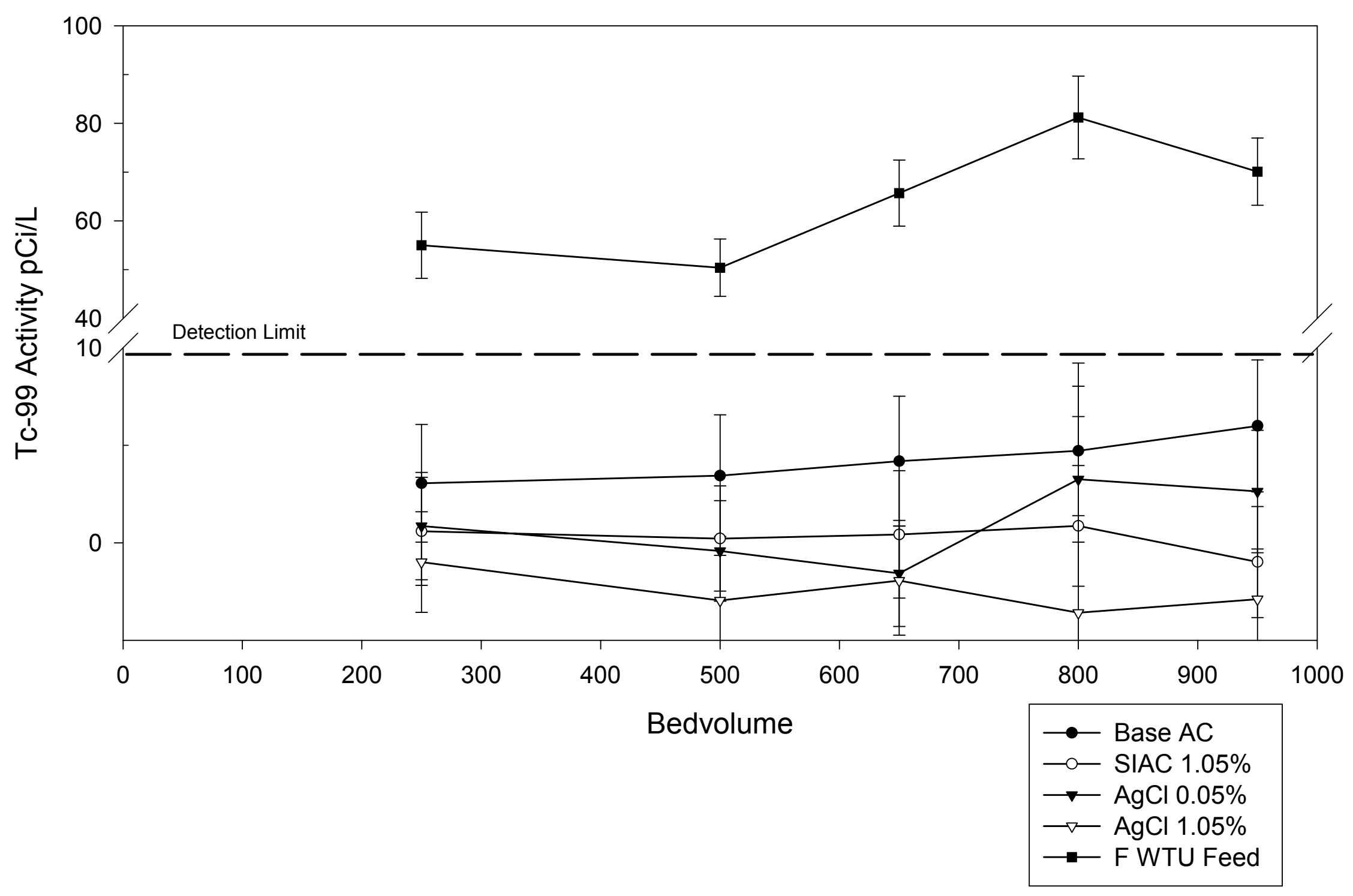

WSRC-TR-2002-00435

Page 32 of 35 
Figure 8 - I-129 Effluent Activity for Concept 3 (Anion Resin).

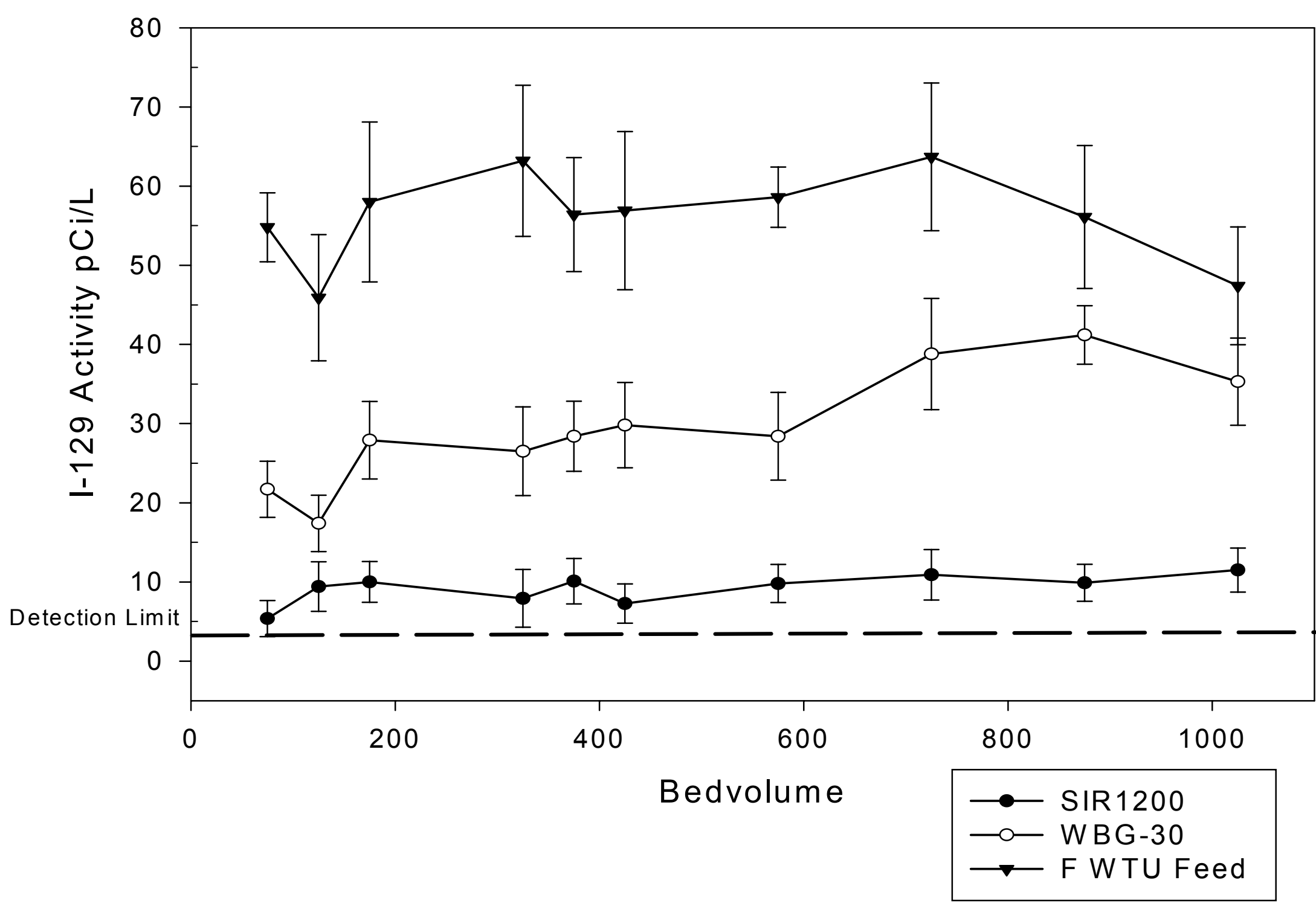

WSRC-TR-2002-00435

Page 33 of 35 
WSRC-TR-2002-00435

Page 34 of 35 


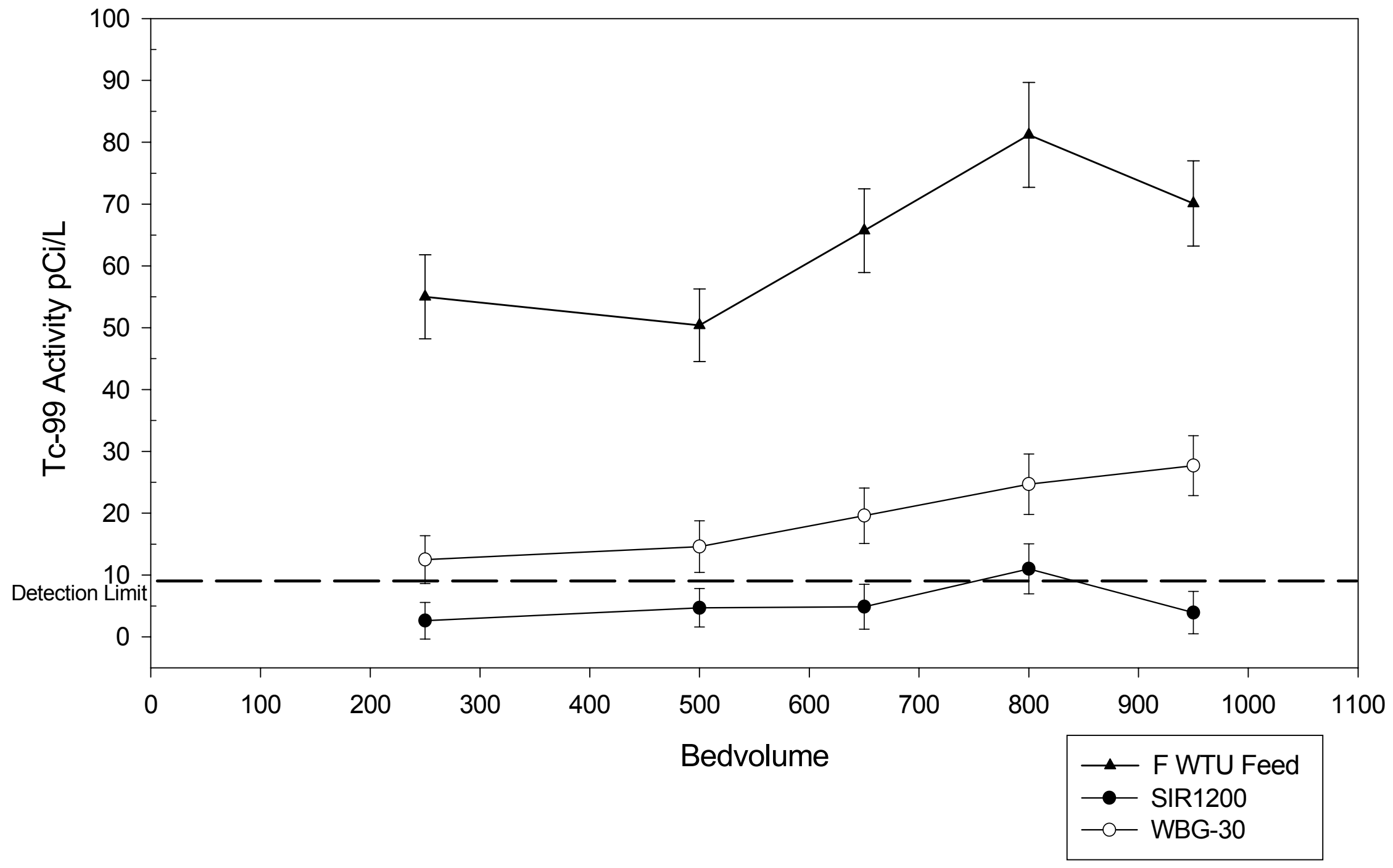

Figure 9 - Tc-99 Effluent Activity for Concept 3 (Anion Resin). 


\section{Appendix A (Email From Butcher 7/9/02)}

Good morning Steve. Sorry about the late night call. Here are the disposal costs and waste volumes:

\section{Disposal Costs}

Trench \$ $106 / \mathrm{m}^{3}$

LAWV $\quad \$ 1161 / \mathrm{m}^{3}$

Offsite $\quad \$ 1400 / \mathrm{m}^{3}$

Disposal Volumes (10 year forecast)*

ETF: $\quad$ Carbon $150 \mathrm{~m}^{3}$ (suitable only for vault disposal due to tritium)

$$
\text { GT-73 Resin } 15 \mathrm{~m}^{3}
$$

FWTU: Filtercake $\quad 3570 \mathrm{~m}^{3}$

CG8 $\quad 1100 \mathrm{~m}^{3}$

Dowex $520 \mathrm{~m}^{3}$

Carbon $4 \mathrm{~m}^{3}$

HWTU: $\quad$ CG8 $\quad 390 \mathrm{~m}^{3}$

Dowex $231 \mathrm{~m}^{3}$

Filtercake $\quad 22 \mathrm{~m}^{3}$

Carbon $\quad 4 \mathrm{~m}^{3}$

* Source: Memo, Hudson to Sauls, 9/5/01. 
Appendix B

Full ICP-ES Elemental Data

WSRC-TR-2002-00435

Page B1 of B6 


\section{Feedwater}

\begin{tabular}{|c|c|c|c|c|c|c|c|c|c|c|c|c|c|c|c|}
\hline ab ID & & C9-1L & $9-21$ & C9-3L & C94L & C96L & C9.7 & $\mathrm{Ca-8}$ & 20 & C9-11L & $C_{-12}$ & C9-14 & $\mathrm{C}_{-15}$ & C9-17 & $9-18$ \\
\hline DSID & & 016898 & 168982 & 300168983 & 300168984 & 4300168985 & 5300168986 & 300168987 & 00168988 & 300168989 & 9300168990 & 300168991 & 1300168992 & 300168993 & 300168994 \\
\hline Effluent Vd. (L) & $\mathrm{MD}$ (ppm) & 1 & 2 & 3 & 4 & 6 & 7 & 8 & 9 & 11 & 12 & 14 & 15 & 17 & 18 \\
\hline Bedvdmes & & 100 & 150 & 200 & 250 & 350 & 400 & 450 & 500 & 600 & 650 & 750 & 800 & 900 & 950 \\
\hline $\mathrm{Ag}$ & 0.008 & 0.0021 & 0.0029 & 0.0018 & 0.0022 & 0.0036 & 0.0039 & 0.0040 & 0.0289 & 0.0160 & 0.0116 & 0.0106 & 0.0115 & 0.0130 & 0.0127 \\
\hline A & 0.057 & 14.5991 & 14.7596 & 14.5146 & $14.55 / 5$ & $5 \quad 14.5646$ & 14.5292 & 14.5349 & 14.2055 & $5 \quad 14.0910$ & 14.0663 & 14.0941 & 14.0446 & 14.1510 & 14.2002 \\
\hline B & 0.028 & 0.0042 & 0.0045 & 0.0033 & 0.0056 & 0.0045 & 0.0039 & 0.0007 & 0.0020 & -0.0010 & 0.0031 & -0.0011 & 0.0022 & 0.0012 & 0.0022 \\
\hline $\mathrm{Ba}$ & 0.019 & 0.2394 & 0.2433 & 0.2375 & 0.2387 & 0.2374 & 0.2389 & 0.2381 & 0.2824 & 0.2650 & 0.2586 & 0.2550 & 0.2582 & 0.2621 & 0.2617 \\
\hline a & 0.023 & 8.2482 & 8.2621 & 8.1880 & 8.1291 & 8.1234 & 8.1742 & 8.2584 & 8.8090 & 8.8110 & 8.9740 & 8.7351 & 8.8640 & 8.8567 & 8.8907 \\
\hline$C \mathrm{~d}$ & 0.0042 & 0.0074 & 0.0061 & 0.0072 & 0.0065 & 0.0070 & 0.0072 & 0.0072 & 0.0072 & 0.0080 & 0.0073 & 0.0069 & 0.0073 & 0.0063 & 0.0077 \\
\hline or & 0.006 & 0.1950 & 0.2066 & 0.1889 & 0.1866 & 0.1900 & 0.2041 & 0.2090 & 0.4423 & 0.3190 & 0.2784 & 0.2682 & 0.2838 & 0.2038 & 0.2852 \\
\hline a & 0.0048 & -0.0030 & -0.0047 & -0.0042 & -0.0043 & -0.0038 & -0.0046 & -0.0041 & -0.0045 & -0.0030 & -0.0049 & -0.0036 & -0.0035 & -0.0033 & -0.0037 \\
\hline $\mathrm{Fe}$ & 0.0036 & 0470 & 0.0440 & 0.0425 & 0.0408 & 0.0390 & 0.0381 & 0.0386 & 0.0390 & 0.0390 & 0.0391 & 0.0393 & 0.0394 & 0.0399 & 0.0395 \\
\hline K & 0.938 & 0.0069 & 0.0052 & 0.0033 & 0.0018 & 0.0022 & 0.0057 & 0.0016 & 0.0017 & 0.0030 & 0.0027 & 0.0013 & 0.0013 & 0.0012 & 0.0015 \\
\hline La & 0.0072 & 0.0238 & 0.0251 & 0.0228 & 0.0232 & 0.0236 & 0.0254 & 0.0257 & 0.0571 & 0.0420 & 0.0351 & 0.0339 & 0.0348 & 0.0375 & 0.0366 \\
\hline 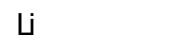 & .043 & 0.6700 & 0.9788 & 0.9231 & 0.9665 & 0.7386 & 0.8364 & 0.8562 & 0.7439 & 0.6870 & 0.6008 & 0.6073 & 0.7671 & 1.1096 & 1.1090 \\
\hline $\mathrm{gg}$ & 0.0053 & 0.0344 & 0.0353 & 0.0323 & 0.0326 & 0.0330 & 0.0334 & 0.0359 & 0.0727 & 0.0530 & 0.0459 & 0.0474 & 0.0471 & 0.0489 & 0.0488 \\
\hline $\mathrm{Mh}$ & 0.0008 & -0.0013 & 0.0002 & -0.0016 & -0.0016 & 0.0013 & 0.0014 & 0.0026 & 0.0555 & 0.0300 & 0.0185 & 0.0179 & 0.0196 & 0.0222 & 0.0206 \\
\hline $\mathrm{Vb}$ & .053 & 3820 & 3.4371 & 3.3885 & 3.3938 & 3.4056 & 3.4207 & 3.4306 & 3.6643 & 3.6140 & 3.5609 & 3.5381 & 3.5747 & 3.5981 & 3.6106 \\
\hline $\mathrm{Na}$ & 0.022 & 1.3824 & 1.4042 & 1.3834 & 1.3807 & 1.3820 & 1.3962 & 1.3907 & 1.4742 & 1.4610 & 1.4428 & 1.4367 & 1.4475 & 1.4592 & 1.4676 \\
\hline $\mathrm{N}$ & 0.0135 & 0.0266 & 0.0283 & 0.0213 & 0.0248 & 0.0200 & 0.0238 & 0.0089 & 0.1150 & 0.0660 & 0.0638 & 0.0510 & 0.0536 & 0.0792 & 0.0703 \\
\hline$P$ & 0.069 & 33.0950 & 33.3369 & 329096 & 327341 & $1 \quad 326474$ & 325840 & 325405 & 33.9413 & 34.0810 & 34.4469 & 34.8240 & 34.7788 & 34.9878 & 35.3079 \\
\hline $\mathrm{Pb}$ & 0.0319 & 0.0274 & 0.0272 & 0.0253 & 0.0232 & 0.0254 & 0.0251 & 0.0265 & 0.0189 & 0.0280 & 0.0267 & 0.0176 & 0.0259 & 0.0264 & 0.0278 \\
\hline $\mathrm{Sb}$ & 0.378 & -0.0662 & -0.0469 & -0.0475 & -0.0306 & -0.0862 & -0.0866 & -0.0724 & -0.0818 & -0.0760 & -0.0598 & -0.1106 & -0.0777 & -0.0835 & -0.0752 \\
\hline S & 0.0167 & 0.0002 & 0.0027 & -0.0086 & 0.0017 & 0.0022 & 0.0110 & 0.0003 & 0.0122 & 0.0040 & 0.0065 & -0.0056 & 0.0051 & -0.015 & 0.0007 \\
\hline Sn & 0.045 & 0.0676 & 0.0518 & 0.0547 & 0.0512 & 0.0596 & 0.0596 & 0.0643 & 0.1483 & 0.0980 & 0.1014 & 0.0712 & 0.0904 & 0.1020 & 0.1013 \\
\hline 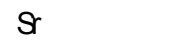 & 0.0076 & 19.5011 & 19.7698 & 19.4737 & 19.4459 & $\begin{array}{ll}9 & 19.4529\end{array}$ & 19.5205 & 19.5413 & 20.9839 & 20.5740 & 20.3219 & 20.2970 & 20.4456 & 20.5894 & 20.6873 \\
\hline$\pi$ & 0.0077 & 0.0692 & 0.0791 & 0.0569 & 0.0514 & 0.0734 & 0.0658 & 0.0590 & 0.2366 & 0.1460 & 0.1302 & 0.1380 & 0.1287 & 0.1416 & 0.1343 \\
\hline & 0.5 & 1.7143 & 1.7172 & 1.6996 & 1.7000 & 1.6974 & 1.7040 & 1.7145 & 1.5063 & 1.5200 & 1.5617 & 1.5183 & 1.5207 & 1.5161 & 1.5088 \\
\hline & 0.0032 & -0.0027 & -0.0024 & -0.0029 & -0.0024 & -0.0030 & -0.0027 & -0.0029 & -0.0017 & -0.0030 & -0.0032 & -0.0029 & -0.0026 & -0.0031 & -0.0029 \\
\hline & 0.0228 & 0.7484 & 0.7920 & 0.7413 & 0.7451 & 0.7739 & 0.7725 & 0.7619 & 1.1254 & 0.9200 & 0.8516 & 0.8486 & 0.8636 & 0.8836 & 0.8821 \\
\hline
\end{tabular}




\section{$1.05 \%$ SIAC-Ag(0) Effluent}

\begin{tabular}{|c|c|c|c|c|c|c|c|c|c|c|c|c|c|c|c|}
\hline Lab ID & & C2-1L & C2-2L & C2-3L & C2-4L & C2-6L & C2-7L & C2-8L & C2-9L & C2-11L & C2-12 & C2-14L & C2-15L & C2-17L & C2-18L \\
\hline ADSID & & 300169011 & 300169012 & 300169013 & 300169014 & 300169015 & 300169016 & 300169017 & 300169018 & 300169019 & 300169020 & 300169021 & 300169022 & 300169023 & 300169024 \\
\hline Effluent Vol. & MDL (ppm) & 1 & 2 & 3 & 4 & 6 & 7 & 8 & 9 & 11 & 12 & 14 & 15 & 17 & 18 \\
\hline Bedvolmes & & 100 & 150 & 200 & 250 & 350 & 400 & 450 & 500 & 600 & 650 & 750 & 800 & 900 & 950 \\
\hline $\mathrm{Ag}$ & 0.008 & 0.073 & 0.174 & 1.42 & 13.9 & 13.4 & 9.69 & 5.63 & 1.52 & 0.855 & 0.678 & 0.657 & 0.670 & 0.596 & 0.441 \\
\hline $\bar{A}$ & 0.05 & 1.69 & 9.41 & 129 & 15.1 & 15.4 & 15.5 & 15.8 & 15.8 & 16.0 & 16.0 & 15.7 & 15.4 & 15.1 & 14.7 \\
\hline $\bar{B}$ & 0.028 & $\varangle .031$ & $\varangle .031$ & $\varangle .031$ & $\varangle .031$ & $\varangle .031$ & $<0.031$ & $<0.031$ & $\varangle .031$ & $<0.031$ & $\varangle 0.031$ & $\varangle 0.031$ & $\varangle 0.031$ & $\varangle 0.031$ & $\varangle .031$ \\
\hline $\mathrm{Ba}$ & 0.019 & 0.186 & 0.265 & 0.258 & 0.249 & 0.245 & 0.242 & 0.246 & 0.243 & 0.238 & 0.247 & 0.243 & 0.238 & 0.244 & 0.242 \\
\hline $\mathrm{Ca}$ & 0.023 & 10.6 & 9.68 & 8.93 & 8.79 & 8.72 & 8.75 & 8.82 & 8.75 & 8.78 & 8.65 & 8.80 & 8.61 & 8.62 & 8.61 \\
\hline $\mathrm{Cd}$ & 0.0042 & $\varangle .005$ & $\varangle .005$ & $\varangle 0.005$ & $\varangle .005$ & $\varangle .005$ & $\varangle 0.005$ & $\varangle .005$ & $\varangle .005$ & 40.005 & 40.005 & $\varangle .005$ & $\varangle 0.005$ & $\varangle 0.005$ & $\varangle .005$ \\
\hline or & 0.006 & $\varangle 0.007$ & $\varangle 0.007$ & $\varangle .007$ & $\varangle .007$ & $\varangle .007$ & $<0.007$ & $\varangle .007$ & $\varangle .007$ & $\varangle .007$ & $\varangle 0.007$ & $\varangle 0.007$ & $\varangle 0.007$ & $\varangle 0.007$ & $\varangle .007$ \\
\hline$\overline{a u}$ & 0.0048 & 0.016 & 0.016 & 0.022 & 0.027 & 0.029 & 0.031 & 0.034 & 0.035 & 0.036 & 0.035 & 0.036 & 0.036 & 0.035 & 0.036 \\
\hline $\mathrm{Fe}$ & 0.0036 & 0.057 & 0.098 & 0.033 & 0.026 & 0.039 & 0.040 & 0.043 & 0.046 & 0.051 & 0.056 & 0.056 & 0.051 & 0.045 & 0.035 \\
\hline $\mathrm{K}$ & 0.938 & 4.03 & $<1.03$ & $<1.03$ & $<1.03$ & $<1.03$ & $<1.03$ & 1.04 & 1.09 & 1.11 & 1.31 & 1.12 & 1.03 & 1.21 & $<1.03$ \\
\hline La & 0.0072 & 0.046 & 0.047 & 0.055 & 0.054 & 0.055 & 0.050 & 0.054 & 0.052 & 0.049 & 0.05 & 0.054 & 0.051 & 0.055 & 0.051 \\
\hline 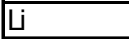 & 0.043 & $\varangle 0.047$ & $\varangle 0.047$ & $\varangle 0.047$ & $\varangle 0.047$ & $\varangle .047$ & 4.047 & 4.047 & $\varangle .047$ & $\varangle .047$ & 4.047 & $\varangle .047$ & $\varangle .047$ & $\varangle 0.047$ & $\varangle .047$ \\
\hline $\mathrm{Mg}$ & 0.0053 & 3.88 & 3.66 & 3.63 & 3.64 & 3.60 & 3.56 & 3.58 & 3.57 & 3.54 & 3.61 & 3.61 & 3.55 & 3.5 & 3.59 \\
\hline $\mathrm{Mn}$ & 0.0008 & 1.80 & 1.75 & 1.54 & 1.48 & 1.45 & 1.44 & 1.44 & 1.43 & 1.42 & 1.44 & 1.44 & 1.42 & 1.43 & 1.43 \\
\hline $\mathrm{Mb}$ & 0.053 & 0.106 & $\varangle 0.058$ & 0.077 & 0.106 & 0.119 & 0.096 & 0.100 & 0.110 & 0.104 & 0.097 & 0.110 & 0.079 & 0.084 & 0.106 \\
\hline $\mathrm{Na}$ & 0.022 & 36.4 & 34.2 & 328 & 33.2 & 33.1 & 33.4 & 33.5 & 33.1 & 33.6 & 32.5 & 33.2 & 32.9 & 329 & 327 \\
\hline $\bar{N}$ & 0.0135 & 0.026 & 0.032 & 0.033 & 0.025 & 0.032 & 0.029 & 0.032 & 0.030 & 0.032 & 0.032 & 0.031 & 0.021 & 0.027 & 0.028 \\
\hline $\mathrm{P}$ & 0.069 & 0.114 & $<0.076$ & $\varangle .076$ & $\varangle .076$ & $\varangle .076$ & $<0.076$ & $\varangle 0.076$ & $\varangle .076$ & $\varangle 0.076$ & $\varangle 0.076$ & $\varangle 0.076$ & $\varangle 0.076$ & $\varangle 0.076$ & $\varangle .076$ \\
\hline $\mathrm{Pb}$ & 0.0319 & $\varangle 0.035$ & $\varangle 0.035$ & $<0.035$ & $\varangle 0.035$ & $\varangle 0.035$ & $\varangle 0.035$ & $\varangle .035$ & $\varangle .035$ & $\varangle .035$ & $\varangle .035$ & $\varangle .035$ & $\varangle 0.035$ & $\varangle 0.035$ & $\varangle .035$ \\
\hline$S b$ & 0.378 & $\varangle 0.416$ & $\varangle 0.416$ & $\varangle 0.416$ & $\varangle 0.416$ & $\varangle 0.416$ & 4.416 & 4.416 & $\varangle .416$ & 40.416 & 40.416 & $\varangle .416$ & 40.416 & $\varangle 0.416$ & $\varangle .416$ \\
\hline Si & 0.0167 & 16.7 & 19.0 & 20.2 & 21.0 & 21.0 & 20.9 & 21.1 & 21.1 & 21.1 & 21.2 & 21.3 & 20.9 & 20.9 & 20.8 \\
\hline$S \mathrm{Sn}$ & 0.045 & 0.250 & 0.215 & 0.251 & 0.272 & 0.263 & 0.243 & 0.272 & 0.253 & 0.255 & 0.286 & 0.275 & 0.239 & 0.273 & 0.278 \\
\hline$S r$ & 0.0076 & 1.79 & 1.64 & 1.48 & 1.45 & 1.46 & 1.45 & 1.44 & 1.44 & 1.44 & 1.45 & 1.43 & 1.44 & 1.41 & 1.40 \\
\hline$T \mathrm{Ti}$ & 0.0077 & $\varangle 0.008$ & $\varangle 0.008$ & $\varangle 0.008$ & $\varangle 0.008$ & $\varangle .008$ & $\varangle .008$ & 40.008 & $\varangle 0.008$ & $\varangle 0.008$ & $\varangle 0.008$ & $\varangle 0.008$ & $\varangle 0.008$ & $\varangle 0.008$ & $\varangle .008$ \\
\hline $\mathrm{U}$ & 0.5 & $\varangle 0.550$ & $\varangle 0.550$ & $\varangle 0.550$ & 0.639 & 0.719 & 0.714 & 0.751 & 0.799 & 0.787 & 0.876 & 0.861 & 0.790 & 0.836 & 0.853 \\
\hline$Z n$ & 0.0032 & 0.005 & 0.030 & 0.029 & 0.021 & 0.021 & 0.019 & 0.022 & 0.021 & 0.024 & 0.026 & 0.021 & 0.018 & 0.019 & 0.022 \\
\hline$Z r$ & 0.0228 & $\varangle 0.025$ & $<0.025$ & $<0.025$ & $\varangle .025$ & $\varangle .025$ & $\varangle 0.025$ & 40.025 & $\varangle 0.025$ & $\varangle 0.025$ & $\varangle 0.025$ & $\varangle 0.025$ & $\varangle 0.025$ & $<0.025$ & $\varangle .025$ \\
\hline
\end{tabular}




\begin{tabular}{|c|c|c|c|c|c|c|c|c|c|c|c|c|c|c|c|}
\hline LabID & & C3-1L & C3-2 & C3-3L & C34L & C36L & C3-7L & C38L & C3-9 & C3-11L & C3-12 & C3-14L & C3-15 & C3-17 & C3-18L \\
\hline ADSID & & 300169026 & 300169027 & 30016908 & 300169029 & 300169030 & 300169031 & 300169032 & 300169033 & 300169034 & 300169035 & 300169036 & 300169037 & 300169038 & 300169039 \\
\hline Effluent Vd. & MD_(ppm) & 1 & 2 & 3 & 4 & 6 & 7 & 8 & 9 & 11 & 12 & 14 & 15 & 17 & 18 \\
\hline Bedudmes & & 100 & 150 & 200 & 250 & 350 & 400 & 450 & 500 & 600 & 650 & 750 & 800 & 900 & 950 \\
\hline $\mathrm{Ag}$ & 0.008 & 0.052 & 0.365 & 0.321 & 0.298 & 0.274 & 0.262 & 0.266 & 0.139 & 0.079 & 0.062 & 0.041 & 0.040 & 0.040 & 0.035 \\
\hline$A$ & 0.056 & 10.6 & 14.6 & 14.8 & 14.8 & 14.7 & 14.5 & 14.5 & 14.5 & 14.5 & 14.5 & 14.4 & 14.6 & 14.6 & 14.5 \\
\hline$B$ & 0.028 & 0.296 & $\varangle .031$ & $\varangle .031$ & $\varangle .031$ & 40.031 & $\varangle .031$ & $\varangle .031$ & 4.001 & $\varangle 0.031$ & $\varangle .031$ & $\varangle .031$ & $\varangle .031$ & $\varangle .031$ & 40.031 \\
\hline $\mathrm{Ba}$ & 0.019 & 0.313 & 0.276 & 0.236 & 0.240 & 0.232 & 0.224 & 0.234 & 0.232 & 0.236 & 0.233 & 0.223 & 0.230 & 0.236 & 0.236 \\
\hline $\mathrm{Ca}$ & 0.023 & 10.5 & 8.53 & 8.42 & 8.37 & 8.31 & 8.33 & 8.44 & 8.51 & 8.45 & 8.51 & 8.50 & 8.49 & 8.58 & 8.53 \\
\hline $\mathrm{Cd}$ & 0.0042 & 40.006 & 40.005 & 40.006 & 40.006 & 40.005 & 80.005 & 40.006 & 4.005 & 4.005 & 40.005 & 4.005 & 4.005 & 40.006 & 40.005 \\
\hline ar & 0.006 & 8.007 & 40.007 & 40.007 & 40.007 & 80.007 & $\varangle 0.007$ & 80.007 & $\varangle .007$ & 8.007 & $\varangle 0.007$ & 8.007 & $\varangle .007$ & $\varangle .007$ & $\varangle .007$ \\
\hline au & 0.0048 & 0.020 & 0.027 & 0.029 & 0.031 & 0.032 & 0.032 & 0.033 & 0.034 & 0.032 & 0.034 & 0.033 & 0.034 & 0.033 & 0.035 \\
\hline $\mathrm{Fe}$ & 0.0036 & 0.021 & 0.028 & 0.020 & 0.016 & 0.015 & 0.014 & 0.014 & 0.012 & 0.013 & 0.012 & 0.008 & 0.009 & 0.007 & 0.007 \\
\hline $\mathrm{K}$ & 0.938 & 1.25 & $<1.03$ & $<1.03$ & $<1.09$ & 1.06 & 1.15 & $<1.03$ & 1.60 & $<1.03$ & $<1.03$ & $<1.03$ & 1.24 & $<1.03$ & 1.49 \\
\hline $\mathrm{La}$ & 0.0072 & 0.063 & 0.054 & 0.037 & 0.045 & 0.043 & 0.040 & 0.047 & 0.047 & 0.046 & 0.048 & 0.038 & 0.047 & 0.049 & 0.049 \\
\hline Li & 0.043 & 8.047 & 4.047 & 4.047 & $\varangle 0.047$ & $\varangle 0.047$ & $\varangle 0.047$ & $<0.047$ & 4.047 & 4.047 & $<0.047$ & $\varangle 0.047$ & 40.047 & 4.047 & $\varangle .047$ \\
\hline $\mathrm{Mg}$ & 0.0053 & 3.85 & 3.55 & 3.39 & 3.48 & 3.46 & 3.42 & 3.49 & 3.47 & 3.53 & 3.51 & 3.44 & 3.49 & 3.56 & 3.54 \\
\hline $\mathrm{Mh}$ & 0.0008 & 1.36 & 1.42 & 1.37 & 1.39 & 1.38 & 1.37 & 1.39 & 1.39 & 1.40 & 1.40 & 1.39 & 1.40 & 1.42 & 1.41 \\
\hline $\mathrm{Mb}$ & 0.053 & 0.089 & 0.088 & 40.058 & 0.059 & 0.068 & 0.071 & 0.089 & 0.075 & 0.076 & 0.073 & 0.072 & 0.076 & 0.096 & 0.080 \\
\hline $\mathrm{Na}$ & 0.022 & 34.9 & 33.4 & 34.1 & 33.3 & 33.2 & 33.4 & 33.6 & 33.9 & 33.3 & 33.7 & 34.1 & 33.8 & 33.9 & 33.5 \\
\hline $\mathrm{N}$ & 0.0135 & 0.054 & 0.035 & 0.027 & 0.028 & 0.031 & 0.022 & 0.022 & 0.026 & 0.022 & 0.024 & 0.022 & 0.028 & 0.029 & 0.028 \\
\hline $\mathrm{P}$ & 0.069 & 1.54 & $\varangle .076$ & 0.142 & 0.191 & 0.164 & 0.153 & 0.094 & 40.076 & 40.076 & $<0.076$ & $<0.076$ & 40.076 & $\varangle .076$ & $\varangle .076$ \\
\hline $\mathrm{Pb}$ & 0.0319 & 40.036 & 40.035 & 40.036 & 40.036 & 4.035 & $\varangle 0.035$ & 80.036 & $\varangle 0.036$ & 40.035 & $\varangle 0.035$ & $\varangle .035$ & 40.035 & 40.036 & $\varangle .035$ \\
\hline Sb & 0.378 & 8.416 & 4.416 & 4.416 & 4.416 & $\varangle .416$ & $\varangle 0.416$ & $\varangle 0.416$ & 4.416 & 4.416 & $\varangle 0.416$ & $\varangle 0.416$ & 4.416 & 4.416 & 4.416 \\
\hline S & 0.0167 & 20.3 & 20.3 & 19.7 & 20.0 & 19.9 & 19.7 & 20.1 & 20.1 & 20.3 & 20.2 & 20.0 & 20.1 & 20.5 & 20.4 \\
\hline Sh & 0.045 & 0.191 & 0.216 & 0.133 & 0.179 & 0.180 & 0.162 & 0.212 & 0.208 & 0.208 & 0.209 & 0.188 & 0.242 & 0.269 & 0.252 \\
\hline$S$ & 0.0076 & 203 & 1.56 & 1.53 & 1.50 & 1.51 & 1.51 & 1.48 & 1.49 & 1.48 & 1.46 & 1.48 & 1.47 & 1.47 & 1.48 \\
\hline $\mathrm{Ti}$ & 0.0077 & $\varangle .008$ & $\varangle 0.008$ & 40.008 & 40.008 & $\varangle 0.008$ & $\varangle 0.008$ & $\varangle 0.008$ & 40.008 & 40.008 & $\varangle 0.008$ & $\varangle .008$ & 4.008 & $\varangle .008$ & $\varangle .008$ \\
\hline $\mathrm{U}$ & 0.5 & $\varangle .550$ & $\varangle .550$ & 4.550 & 0.620 & 0.637 & 0.610 & 0.713 & 0.734 & 0.746 & 0.746 & 0.660 & $0.7 / 5$ & 0.792 & 0.784 \\
\hline$Z n$ & 0.0032 & 0.026 & 0.024 & 0.019 & 0.019 & 0.018 & 0.017 & 0.020 & 0.019 & 0.023 & 0.022 & 0.016 & 0.017 & 0.018 & 0.019 \\
\hline Zr & 0.0228 & 40.025 & 40.025 & 40.025 & 40.025 & 80.025 & $\varangle 0.025$ & 80.025 & 4.025 & 40.025 & $\varangle 0.025$ & $\varangle .025$ & 40.025 & 40.025 & $\varangle 0.025$ \\
\hline
\end{tabular}




\section{$1.05 \%$ SIAC-AgCI Effluent}

\begin{tabular}{|c|c|c|c|c|c|c|c|c|c|c|c|c|c|c|c|}
\hline LabID & & C41L & C42 & C43L & C44L & C4A & C4A & C4R & C4g & C411L & C412 & C414L & C415 & C417 & C418 \\
\hline ADSID & & 300168906 & 300163907 & 300168908 & 300169909 & 300168910 & 300169911 & 300168912 & 300169913 & 300168914 & 300163915 & 300168916 & 300168917 & 300168918 & 300163919 \\
\hline Effluent Vd. & $\mathrm{MD}$ (ppm) & 1 & 2 & 3 & 4 & 6 & 7 & 8 & 9 & 11 & 12 & 14 & 15 & 17 & 18 \\
\hline Bedvdmes & & 100 & 150 & 200 & 250 & 350 & 400 & 450 & 500 & 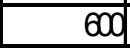 & 650 & 750 & 800 & 900 & 960 \\
\hline $\mathrm{Ag}$ & 0.008 & 0.036 & 0.066 & 0.279 & 0.307 & 0.314 & 0.324 & 0.336 & 0.338 & 0.338 & 0.336 & 0.356 & 0.343 & 0.338 & 0.322 \\
\hline A & 0.05 & 13.3 & 13.9 & 14.2 & 14.1 & 14.2 & 14.2 & 14.2 & 14.2 & 14.3 & 14.2 & 14.3 & 14.1 & 14.3 & 14.2 \\
\hline$B$ & 0.028 & 0.032 & $\varangle .031$ & 4.031 & 4.031 & $\varangle .031$ & 4.031 & $\varangle .031$ & 4.0031 & 4.031 & 4.031 & $\varangle .031$ & $\varangle .031$ & 4.031 & $\varangle .031$ \\
\hline $\mathrm{Ba}$ & 0.019 & 0.236 & 0.244 & 0.244 & 0.247 & 0.244 & 0.246 & 0.248 & 0.246 & 0.251 & 0.249 & 0.253 & 0.248 & 0.258 & 0.253 \\
\hline $\mathrm{Ca}$ & 0.023 & 7.91 & 8.06 & 8.06 & 7.97 & 7.99 & 8.02 & 8.04 & 8.09 & 8.30 & 8.23 & 8.30 & 8.21 & 8.36 & 8.39 \\
\hline $\mathrm{Cd}$ & 0.0042 & 4.006 & 40.005 & 4.006 & 40.006 & 40.005 & 40.005 & 40.006 & $\varangle .005$ & 4.006 & 40.000 & 8.005 & 40.005 & 4.006 & 40.006 \\
\hline$\alpha$ & 0.006 & 4.000 & 40.007 & 4.007 & 4.007 & 40.007 & 40.007 & 40.007 & 40.007 & 4.007 & 40.007 & 40.007 & 40.007 & 4.007 & 40.007 \\
\hline$a$ & 0.0048 & 0.028 & 0.028 & 0.032 & 0.036 & 0.036 & 0.037 & 0.038 & 0.038 & 0.042 & 0.042 & 0.043 & 0.044 & 0.044 & 0.043 \\
\hline $\mathrm{Fe}$ & 0.0036 & 0.083 & 0.030 & 0.036 & 0.030 & 0.027 & 0.028 & 0.029 & 0.026 & 0.024 & 0.083 & 0.02 & 0.019 & 0.018 & 0.016 \\
\hline $\mathrm{K}$ & 0.938 & 40.026 & 40.026 & 0.000 & 0.033 & 0.029 & 0.030 & 0.034 & 0.031 & 0.038 & 0.037 & 0.039 & 0.037 & 0.044 & 0.040 \\
\hline La & 0.0072 & $<1.09$ & $<1.03$ & $<1.0$ & $<1.0$ & $<1.03$ & $<1.09$ & 1.10 & $<1.03$ & $<1.03$ & $<1.09$ & $<1.03$ & $<1.03$ & $<1.09$ & $<1.03$ \\
\hline نا & 0.043 & 0.03 & 0.034 & 0.038 & 0.036 & 0.034 & 0.035 & 0.039 & 0.036 & 0.042 & 0.039 & 0.042 & 0.039 & 0.039 & 0.040 \\
\hline $\mathrm{Mg}$ & 0.005 & 3.42 & 3.46 & 3.48 & 3.51 & 3.47 & 3.48 & 3.49 & 3.50 & 3.48 & 3.47 & 3.51 & 3.46 & 3.56 & 3.51 \\
\hline $\mathrm{Mh}$ & 0.0008 & 1.36 & 1.39 & 1.40 & 1.41 & 1.39 & 1.40 & 1.40 & 1.40 & 1.39 & 1.38 & 1.39 & 1.37 & 1.40 & 1.39 \\
\hline $\mathrm{Mb}$ & 0.053 & 4.068 & 40.068 & 40.058 & 40.058 & 40.068 & 40.058 & 40.068 & 40.058 & 40.058 & 40.068 & 40.058 & 40.058 & 40.058 & $\varangle .058$ \\
\hline $\mathrm{Na}$ & 0.02 & 323 & 327 & 328 & 322 & 324 & 326 & 326 & 327 & 33.7 & 334 & 33.6 & 33.4 & 33.6 & 33.7 \\
\hline $\mathrm{N}$ & 0.013 & 0.028 & 0.022 & 0.021 & 0.027 & 0.018 & 0.020 & 0.019 & 0.02 & 0.020 & 0.017 & 0.020 & 0.027 & 0.015 & 0.029 \\
\hline $\mathrm{P}$ & 0.069 & 40.076 & 40.076 & 40.076 & 40.076 & 40.076 & 40.076 & 40.076 & 40.076 & 40.076 & 40.076 & 40.076 & 40.076 & 40.076 & 40.076 \\
\hline $\mathrm{Pb}$ & 0.0319 & 40.036 & 4.035 & 40.036 & 40.036 & 4.035 & 40.035 & 40.036 & 40.036 & 40.036 & 40.036 & 40.035 & 4.035 & 40.036 & 40.036 \\
\hline Sb & 0.378 & 8.416 & $\varangle 0.416$ & 4.416 & 40.416 & $\Varangle 0.416$ & 4.416 & 4.416 & $\varangle 0.416$ & 4.416 & 4.416 & 80.416 & $\varangle 0.416$ & 4.416 & $\varangle 0.416$ \\
\hline S & 0.016 त्त्र & 20.0 & 20.0 & 20.1 & 20.3 & 20.1 & 20.1 & 20.2 & 20.2 & 20.2 & 20.1 & 20.3 & 20.0 & 20.5 & 20.3 \\
\hline Sh & 0.045 & 40.050 & 40.050 & 8.060 & 40.050 & 40.050 & 40.050 & 40.060 & $\varangle 0.050$ & 0.071 & 0.069 & 0.066 & 0.062 & 0.000 & 80.050 \\
\hline$S$ & 0.0076 & 1.39 & 1.40 & 1.39 & 1.38 & 1.39 & 1.39 & 1.39 & 1.37 & 1.31 & 1.29 & 1.30 & 1.29 & 1.30 & 1.29 \\
\hline $\mathrm{Ti}$ & 0.007 & 0.009 & 40.008 & 4.008 & 40.008 & 40.008 & 40.008 & 40.008 & 40.008 & 40.008 & 40.008 & 40.008 & 40.008 & 40.008 & 40.008 \\
\hline $\mathrm{U}$ & 0.5 & $\varangle .550$ & 40.550 & 4.550 & 0.598 & 0.62 & 0.640 & 0.682 & 0.69 & 0.887 & 0.839 & 0.931 & $0.8 / 5$ & 0.987 & 0.914 \\
\hline$Z n$ & 0.0032 & 0.044 & 0.042 & 0.040 & 0.040 & 0.038 & 0.039 & 0.042 & 0.042 & 0.047 & 0.044 & 0.040 & 0.040 & 0.042 & 0.045 \\
\hline$\overline{Z r}$ & 0.0228 & $\varangle .025$ & 40.025 & 40.025 & 40.025 & 40.025 & 40.025 & 40.025 & 40.025 & 40.025 & 40.025 & 0.027 & 40.025 & 0.029 & 0.026 \\
\hline
\end{tabular}


SIR-1200 Effluent

\begin{tabular}{|c|c|c|c|c|c|c|c|c|c|c|c|c|c|c|c|}
\hline Lab ID & & C7-1L & C7-2L & C7-3L & C7-4L & C7-6L & \begin{tabular}{|l|} 
C7-7L \\
\end{tabular} & C7-8L & C7-9L & C7-11L & C7-12L & C7-14L & C7-15L & C7-17L & C7-18L \\
\hline ADS ID & & 300168951 & 300168952 & 300168953 & 300168954 & 300168955 & 300168956 & 300168957 & 300168958 & 300168959 & 300168960 & 300168961 & 300168962 & 300168963 & 300168964 \\
\hline Effluent Vol. & MDL (ppm) & 1 & 2 & 3 & 4 & 6 & 7 & 8 & 9 & 11 & 12 & 14 & 15 & 17 & 18 \\
\hline Bedvolmes & & 100 & 150 & 200 & 250 & 350 & 400 & 450 & 500 & 600 & 650 & 750 & 800 & 900 & 950 \\
\hline $\mathrm{Ag}$ & 0.005 & $\overline{N A}$ & $\mathrm{NA}$ & $\mathrm{NA}$ & 0.0100 & 0.0100 & 0.0100 & 0.0100 & 0.0100 & 0.0100 & 0.0100 & 0.0100 & $\overline{0.0100}$ & 0.0100 & 0.0100 \\
\hline $\mathrm{B}$ & 0.003 & $\mathrm{NA}$ & $\mathrm{NA}$ & $\mathrm{NA}$ & 0.0060 & 0.0060 & 0.0060 & 0.0060 & 0.0060 & 0.0060 & 0.0010 & 0.0060 & 0.0060 & 0.0060 & 0.0060 \\
\hline $\mathrm{Ba}$ & 0.003 & $\mathrm{NA}$ & NA & $\mathrm{NA}$ & 0.2540 & 0.2540 & 0.2550 & 0.2540 & 0.2510 & 0.2520 & 0.2470 & 0.2470 & 0.2480 & 0.2490 & 0.2470 \\
\hline $\mathrm{Ca}$ & 0.001 & $\mathrm{NA}$ & $\mathrm{NA}$ & $\mathrm{NA}$ & 8.7130 & 8.6800 & 8.6980 & 8.6490 & 8.5530 & 8.5450 & 8.4860 & 8.5260 & 8.5560 & 8.6390 & 8.5610 \\
\hline $\mathrm{Cd}$ & 0.002 & $\mathrm{NA}$ & $\mathrm{NA}$ & $\mathrm{NA}$ & 0.0070 & 0.0110 & 0.0090 & 0.0090 & 0.0070 & 0.0080 & 0.0070 & 0.0070 & 0.0100 & 0.0070 & 0.0070 \\
\hline Co & 0.003 & $\mathrm{NA}$ & $\mathrm{NA}$ & $\mathrm{NA}$ & 0.0880 & 0.0900 & 0.0890 & 0.0920 & 0.0810 & 0.0820 & 0.0850 & 0.0840 & 0.0910 & 0.0940 & 0.0930 \\
\hline $\mathrm{Cr}$ & 0.009 & $\mathrm{NA}$ & $\mathrm{NA}$ & $\mathrm{NA}$ & 0.0180 & 0.0180 & 0.0180 & 0.0180 & 0.0180 & 0.0180 & 0.0110 & 0.0180 & 0.0180 & 0.0180 & 0.0180 \\
\hline $\mathrm{Cu}$ & 0.003 & $\overline{N A}$ & $\mathrm{NA}$ & $\mathrm{NA}$ & 0.0230 & 0.0240 & 0.0230 & 0.0230 & 0.0220 & 0.0220 & 0.0220 & 0.0220 & 0.0240 & 0.0230 & 0.0230 \\
\hline $\mathrm{Fe}$ & 0.004 & NA & NA & NA & 0.0160 & 0.0210 & 0.0110 & 0.0130 & 0.0110 & 0.0110 & 0.0130 & 0.0120 & 0.0150 & 0.0100 & 0.0130 \\
\hline $\mathrm{La}$ & 0.010 & $\overline{N A}$ & $\mathrm{NA}$ & $\mathrm{NA}$ & 0.0200 & 0.0200 & 0.0200 & 0.0200 & 0.0200 & 0.0200 & 0.0290 & 0.0310 & 0.0240 & 0.0310 & 0.0200 \\
\hline $\mathrm{Li}$ & 0.003 & $\mathrm{NA}$ & $\mathrm{NA}$ & $\mathrm{NA}$ & 0.0070 & 0.0080 & 0.0070 & 0.0070 & 0.0060 & 0.0070 & 0.0070 & 0.0060 & 0.0080 & 0.0070 & 0.0070 \\
\hline $\mathrm{Mg}$ & 0.001 & $\mathrm{NA}$ & $\mathrm{NA}$ & $\mathrm{NA}$ & 3.6960 & 3.6960 & 3.7130 & 3.6920 & 3.6440 & 3.6690 & 3.6250 & 3.6160 & 3.6540 & 3.6500 & 3.6240 \\
\hline $\mathrm{Mn}$ & 0.001 & NA & $\mathrm{NA}$ & $\mathrm{NA}$ & 1.5010 & 1.5010 & 1.5060 & 1.4990 & 1.4780 & 1.4850 & 1.4510 & 1.4480 & 1.4620 & 1.4670 & 1.4570 \\
\hline Mo & 0.003 & $\mathrm{NA}$ & $\mathrm{NA}$ & $\mathrm{NA}$ & 0.0060 & 0.0090 & 0.0060 & 0.0090 & 0.0060 & 0.0090 & 0.0030 & 0.0060 & 0.0120 & 0.0120 & 0.0130 \\
\hline $\mathrm{Na}$ & 0.015 & $\mathrm{NA}$ & $\mathrm{NA}$ & $\mathrm{NA}$ & 33.3550 & 33.1720 & 33.4840 & 33.3750 & 33.2630 & 33.3130 & 32.4850 & 32.6640 & 32.2900 & 32.6510 & 32.6480 \\
\hline $\mathrm{Ni}$ & 0.009 & $\overline{\mathrm{NA}}$ & NA & NA & 0.0270 & 0.0280 & 0.0250 & 0.0250 & 0.0260 & 0.0300 & 0.0370 & 0.0420 & 0.0510 & 0.0440 & 0.0480 \\
\hline$P$ & 0.035 & $\mathrm{NA}$ & $\mathrm{NA}$ & $\mathrm{NA}$ & 0.0700 & 0.0700 & 0.0700 & 0.0700 & 0.0700 & 0.0700 & 0.0190 & 0.0700 & 0.0700 & 0.0700 & 0.0700 \\
\hline $\mathrm{Si}$ & 0.015 & NA & NA & $\mathrm{NA}$ & 20.4670 & 20.3840 & 20.4780 & 20.3940 & 20.2230 & 20.2980 & 19.9550 & 19.9720 & 19.9810 & 20.0750 & 20.0140 \\
\hline Sn & 0.016 & NA & NA & NA & 0.0340 & 0.0320 & 0.0320 & 0.0320 & 0.0320 & 0.0610 & 0.0100 & 0.0320 & 0.0320 & 0.0320 & 0.0320 \\
\hline $\mathrm{Sr}$ & 0.001 & NA & $\mathrm{NA}$ & $\mathrm{NA}$ & 0.0440 & 0.0440 & 0.0440 & 0.0440 & 0.0430 & 0.0440 & 0.0430 & 0.0430 & 0.0430 & 0.0430 & 0.0430 \\
\hline $\mathrm{Ti}$ & 0.001 & $\mathrm{NA}$ & $\mathrm{NA}$ & $\mathrm{NA}$ & 0.0330 & 0.0330 & 0.0320 & 0.0320 & 0.0310 & 0.0320 & 0.0320 & 0.0310 & 0.0340 & 0.0340 & 0.0350 \\
\hline $\bar{U}$ & 0.077 & NA & NA & $\mathrm{NA}$ & 0.7460 & 0.7360 & 0.7540 & 0.7060 & 1.3090 & 0.7300 & 0.7250 & 0.7920 & 0.7300 & 0.7950 & 0.7890 \\
\hline $\mathrm{V}$ & 0.003 & $\mathrm{NA}$ & $\mathrm{NA}$ & $\mathrm{NA}$ & 0.0060 & 0.0070 & 0.0060 & 0.0060 & 0.0060 & 0.0060 & 0.0040 & 0.0060 & 0.0070 & 0.0070 & 0.0060 \\
\hline$Z n$ & 0.003 & $\overline{\mathrm{NA}}$ & NA & $\overline{\mathrm{NA}}$ & 0.0430 & 0.0410 & 0.0390 & 0.0420 & 0.0410 & 0.0440 & 0.0490 & 0.0430 & 0.0440 & 0.0550 & 0.0440 \\
\hline$Z r$ & \begin{tabular}{l|l|}
0.003 \\
\end{tabular} & $\overline{N A}$ & $\mathrm{NA}$ & $\mathrm{NA}$ & 0.0360 & 0.0390 & 0.0360 & 0.0350 & 0.0310 & 0.0340 & 0.0350 & 0.0350 & 0.0390 & 0.0370 & 0.0360 \\
\hline
\end{tabular}

WSRC-TR-2002-00435

Page B6 of B6 